\title{
Seasonal abundance and egg production rates of Oithona similis and Pseudocalanus elongatus in the northern North Sea: a first comparison of egg-ratio and incubation methods
}

\author{
Karina Drif ${ }^{1}$, Andrew G. Hirst ${ }^{2, *}$, Steve Hay ${ }^{3}$ \\ ${ }^{1}$ School of Life Science, Heriot-Watt University, Edinburgh EH14 4AS, UK \\ ${ }^{2}$ School of Biological and Chemical Sciences, Queen Mary University of London, Mile End Road, London E1 4NS, UK \\ ${ }^{3}$ Marine Scotland, Marine Laboratory, PO Box 101, 375 Victoria Road, Aberdeen AB11 9DB, UK
}

\begin{abstract}
In this study, we examined egg production rates (EPR), clutch sizes, numbers of spawning females and prosome lengths of 2 common marine egg carrying copepods, Oithona similis and Pseudocalanus elongatus, over an annual cycle in the northern North Sea. For both species, we determined EPR using the incubation method, with rates being assessed after $24\left(\mathrm{EPR}_{0-24}\right), 48\left(\mathrm{EPR}_{0-48}\right)$, and between 24 and $48 \mathrm{~h}\left(\mathrm{EPR}_{24-48}\right)$ of incubation. For Oithona similis, EPR were also determined by applying the egg-ratio method $\mathrm{EPR}_{\mathrm{p}}$, allowing a first ever comparison between these 2 approaches. In both species, mean rates of egg production from $\mathrm{EPR}_{24-48}$ incubations were lower on average than from $\mathrm{EPR}_{0-24}$ and $\mathrm{EPR}_{0-48}$ incubations; however, paired $t$-tests showed these differences to be insignificant ( $p>0.05)$. In Oithona similis, the egg-ratio method $\mathrm{EPR}_{\mathrm{p}}$ gave higher rates (mean $\pm 95 \%$ CI: $1.06 \pm 0.476$ eggs female ${ }^{-1} \mathrm{~d}^{-1}$ ) than the incubation method, but only the comparison with $\mathrm{EPR}_{24-48}$ (mean $\pm 95 \%$ CI: $0.51 \pm 0.337$ eggs female $\left.{ }^{-1} \mathrm{~d}^{-1}\right)$ was significantly different $(p=0.031)$. Possible reasons for the differences are explored and recommendations made. EPR were significantly correlated with temperature in $P$. elongatus $(\mathrm{p}<0.05)$, but the correlation was significant in $O$. similis only when using the egg-ratio method ( $\mathrm{p}<0.05)$. Applying a modified Michaelis-Menten relationship showed EPR to be significantly related to chlorophyll $a$ in both species $(p<0.001)$. Changes in prosome lengths explained little of the variability in clutch size in the 2 species over the course of the year. Finally, seasonality in the abundance and biomass of nauplii, copepodites and adults was examined, together with adult female production and weight-specific fecundity rates, and these were compared across a variety of regions.
\end{abstract}

KEY WORDS: Egg production $\cdot$ Copepod $\cdot$ Egg ratio $\cdot$ Incubation $\cdot$ Oithona similis $\cdot$ Pseudocalanus elongatus $\cdot$ Clutch size $\cdot$ North Sea

\section{INTRODUCTION}

Marine pelagic copepods play a pivotal role in the transfer of carbon and energy to higher trophic levels (Dam et al. 1993), and in the export of organic material as faeces and dead bodies from the upper mixed layer (Legendre \& Rivkin 2002). If we are to predict population dynamics and production rates of copepods, we need to understand their reproductive rates. Species of copepods living in mid to high latitudes typically show strong seasonality in their breeding cycles (Mauchline 1998). The timing of reproduction determines the annual productive cycle and the rate of supply of eggs and nauplii, which are important as prey items to many commercially important fish (Economou 1987, McLaren \& Avendaño 1995, Munk 1997, Heath 2007). 
Copepod reproduction therefore has important implications for fish recruitment (Cushing 1975), and the success of other higher trophic levels.

Many studies have examined how copepod egg production rates (EPR) respond to environmental variability. These rates have been found to depend upon food quantity (e.g. Runge 1985, Peterson \& Bellantoni 1987, Uye \& Murase 1997, Koski et al. 2006) and quality, for example, expressed as specific fatty acids (Evjemo et al. 2008, Jónasdóttir et al. 2009). EPR are also commonly found to be strongly temperature dependent (Ward \& Hirst 2007, Liu \& Hopcroft 2008, Bonnet et al. 2009, Devreker et al. 2009). In addition to the combination of temperature and food (see review of Bunker \& Hirst 2004), female size (e.g. Corkett \& McLaren 1969, Halsband \& Hirche 2001) can also be an important determinant of EPR.

The methods for assessing juvenile growth rates can be demanding in terms of effort (Hirst et al. 2005, Kimmerer et al. 2007), while egg production approaches can be more practical when assessing copepod growth and recruitment. Two methods are routinely used to estimate the EPR of marine pelagic copepods: the incubation and the egg-ratio methods (see Runge \& Roff 2000), the former being more widely used. In the incubation method, adult females are collected and incubated in containers with natural seawater as food; as such, this is an ex situ method. Eggs produced are enumerated typically after a 24 or $48 \mathrm{~h}$ period of incubation (Runge \& Roff 2000). In contrast, in the egg-ratio method, EPR are determined by combining estimates of the abundance of eggs and adult females with egg hatch times (e.g. Checkley 1980). The method can therefore be described as being broadly in situ (although the egg hatch times are commonly determined separately by incubation).

There are problems specific to each approach. Incubating animals can lead to container effects, including changes in the vertical migration ambit of the copepods and in the food regime experienced. The eggratio method does not rely on incubation, and hence does not suffer from these problems. The method, however, relies upon the accurate assessment of abundance, and hence may be liable to sampling and enumeration problems. The egg hatch time estimates are also critical to the accuracy of the results. Finally, the method also assumes a steady state, i.e. eggs 'removed' by hatching are replaced by the supply (production) of new eggs.

To date, the egg-ratio and incubation methods have never been compared against one another in sac spawning copepods. Yet, given the ubiquity of egg production measurements, and their importance in copepod dynamics, we need to be sure that the rates we measure are accurate and that the results from these 2 methods are consistent. Although these methods have been applied simultaneously in broadcast spawning copepods, the results are not expected to be similar; indeed, their difference is used to solve for mortality rates of the free eggs (e.g. Peterson \& Kimmerer 1994, Hirst et al. 2007). Sac spawners present the possibility to appropriately determine whether these 2 methods produce similar results. As eggs are carried by females, they should have a mortality rate similar to the adults, thus removing the main cause of divergence between the results of the two methods as seen in broadcast spawners.

The aims of this study are to (1) describe the seasonality of Pseudocalanus elongatus and Oithona similis in the northern North Sea including the seasonality in their EPR (and clutch size) off Stonehaven, Scotland, and the relationship of these rates to temperature, chlorophyll a (chl a) and prosome length, (2) compare EPR for different incubation periods $(0-24,24-48$ and $0-48 \mathrm{~h}$ ), and (3) compare EPR for both incubation and egg-ratio methods. To address the last objective, we examined the ubiquitous species $O$. similis, which is a true sac spawner that retains its eggs within a membrane.

\section{MATERIALS AND METHODS}

Site. This study was undertaken at the Stonehaven site in the northern northwestern North Sea (Fig. 1), which is located $3 \mathrm{~km}$ offshore from the coast $\left(56^{\circ} 57.80^{\prime} \mathrm{N}, 2^{\circ} 06.20^{\prime} \mathrm{W}\right)$, and has a total water column depth of $45 \mathrm{~m}$. This location is being studied as part of an on-going monitoring time series by the Marine Scotland Laboratories, Aberdeen. This site was originally chosen as an accessible location that is representative of the wider region of the northeast coast of Scotland. The northern North Sea at Stonehaven is under the influence of various water masses. One of these, a large tongue of saline water from the Atlantic Ocean (Otto et al. 1990, Fransz et al. 1991), is known as the 'Atlantic Water'. It has a salinity reaching over 35 and can extend from the Orkney Island to the Dogger Bank. Stonehaven is also under the influence of 'North Sea Water', which results from the mixing of the Atlantic Water with the less saline coastal waters, and has a salinity of 34 to 35. Circulation in the North Sea is classically presented as an anticlockwise gyre that is driven mainly by wind forcing. However, this may sometimes be reversed due to wind forcing, and may also split into 2 gyres in the north and in the south, or cease altogether (Kauker \& von Storch 2000, ICES 2005). During the present study, the Stonehaven site was visited on a near fortnightly basis from February 2003 to February 2004. 


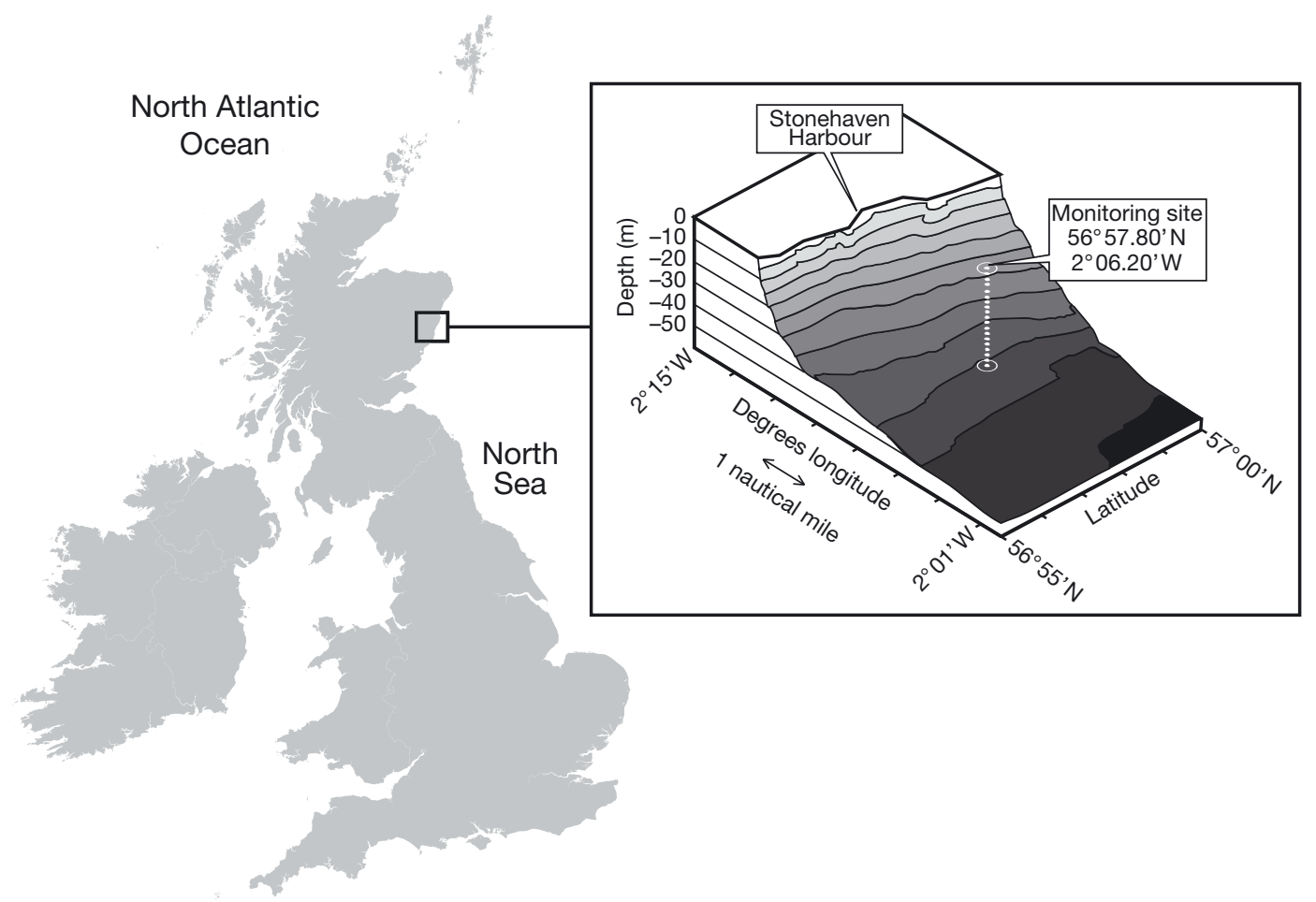

Fig. 1. Location of the Stonehaven site in the northern North Sea

Egg production: incubation method. To determine egg production using the incubation method, we collected copepods by slow vertical tows from $45 \mathrm{~m}$ (near bottom) to the surface using 2 different sized mesh nets (95 or $200 \mu \mathrm{m}$ ) that were fitted with a non-filtering cod end. The contents of the cod end were gently emptied into a $15 \mathrm{l}$ bucket that was freshly rinsed and partly filled with surface seawater. Buckets were topped up and tight fitting lids were used to exclude air and avoid mechanical damage in transit to the laboratory. Natural seawater for use in subsequent incubations was collected from a depth of $5 \mathrm{~m}$ and stored in a $15 \mathrm{l}$ carboy for return to the laboratory.

Upon return to the laboratory (within $2 \mathrm{~h}$ of collection), live copepod samples were sorted in a controlled temperature room set at in situ seawater temperature $\left( \pm 1^{\circ} \mathrm{C}\right)$. Animals were transferred into a plastic petri dish, and non-ovigerous Oithona similis and Pseudocalanus elongatus females were randomly selected using a wide bore pipette. The seawater used for incubations was pre-screened through a $95 \mu \mathrm{m}$ mesh to remove large metazoans while retaining food. Live undamaged females were placed individually in $70 \mathrm{ml}$ plastic tissue flasks filled with incubation water. Flasks were completely filled, and cling film placed over the mouth to prevent the formation of air bubbles. We aimed to incubate $>15$ females of each species, but this was not achieved in 3 of 36 incubations because of the low densities of animals. Incubations began within $6 \mathrm{~h}$ of collection and continued for up to $2 \mathrm{~d}$. Bottles were placed on a plankton wheel that was set to revolve at $0.5 \mathrm{rpm}$, with the flasks rotating end over end. After $24 \mathrm{~h}$, each flask was examined to see if any eggs had been produced. Eggs were counted using a stereomicroscope with variable illumination, without disrupting the sacs on the live animals; the transparent nature of the sac allowed this. Subsequent checks revealed this method to be accurate for the assessment of the number of eggs when compared with counts made by dissecting the egg sacs. After counting, the flasks were replaced on the plankton wheel for a further $24 \mathrm{~h}$. The animals were removed after $48 \mathrm{~h}$, and the eggs dissected from the sacs and counted. The incubation water was also filtered to ensure that any eggs that might have been dislodged (this occasionally occurred for Pseudocalanus) could be included in this count. No eggs hatched before the end of the $48 \mathrm{~h}$. Prosome lengths of the females were also measured upon termination of the experiment using a microscope (Leica MZ75) with a fitted eyepiece graticule (lengths measured to the nearest $9.2 \mu \mathrm{m})$. On 28 July 2003, there was no reproduction in either species and animals suffered very high mortality rates; this data was therefore not included in this study. Oithona similis usually carries 2 sacs clutch $^{-1}$, so the value for clutch size reported here is the total number of eggs carried, i.e. combined from the 2 sacs. Pseudocalanus elongatus produces a single egg mass; hence, this is the value reported here. 
The EPR (eggs female ${ }^{-1} \mathrm{~d}^{-1}$ ) from incubation experiments were calculated as follows:

$$
\mathrm{EPR}=\frac{E}{I \times F}
$$

where $E$ is the total number of eggs produced (estimated after 24 and $48 \mathrm{~h}$ of incubation), $I$ is the incubation period in days (i.e. 1 or $2 \mathrm{~d}$ ), and $F$ is the number of females incubated. Daily EPR rates were determined for the period 0 to 24,24 to 48 and 0 to $48 \mathrm{~h}\left(\mathrm{EPR}_{0-24}\right.$, $\mathrm{EPR}_{24-48}$ and $\mathrm{EPR}_{0-48}$ respectively) to examine the impact of the incubation period on the results.

Egg production: egg-ratio method. The in situ abundance of eggs and adults were determined using collections made with bongo nets of $68 \mu \mathrm{m}$ mesh size (mouth opening diameter $0.3 \mathrm{~m}$ ). This mesh size was chosen to reduce clogging, while ensuring that egg sacs of Oithona would be retained (see Ward \& Hirst 2007). One sample was collected on each visit by hauling the nets vertically over the entire water column ( 0 to $45 \mathrm{~m}$ depth). Samples were preserved in $4 \%$ buffered formaldehyde solution and females and eggs were later counted in subsamples. Between 50 and 100 females of $O$. similis were enumerated and the number of eggs counted. Egg development times, i.e. the time from laying to hatching (HT, days), were predicted using the equation of Nielsen et al. (2002):

$$
\mathrm{HT}=1504.5(T+7.6998)^{-2.05}
$$

Temperature $\left(T,{ }^{\circ} \mathrm{C}\right)$ was measured using electronic reversing thermometers (SIS RTM $4002 \mathrm{X}$ ), and applied here as the average of surface $(1 \mathrm{~m})$ and bottom $(45 \mathrm{~m})$ temperatures, which rarely diverged by $>1^{\circ} \mathrm{C}$ between these 2 depths (see Fig. 2). The eggratio method equation (Edmondson et al. 1962, Checkley 1980) was then applied to determine the daily egg production rates $\left(\mathrm{EPR}_{\mathrm{p}}\right)$ as:

$$
\mathrm{EPR}_{\mathrm{p}}=\frac{E_{\mathrm{p}}}{\left(F_{\mathrm{p}} \times \mathrm{HT}\right)}
$$

where $E_{\mathrm{p}}$ is the abundance of eggs (ind. $\mathrm{m}^{-3}$ ), and $F_{\mathrm{p}}$ the abundance of females (ind $\mathrm{m}^{-3}$ ).

Chl a concentration was determined from water collected using a Lund tube, sampling the top $10 \mathrm{~m}$ of the water column. Duplicate samples (1 l each) were GF/F filtered. Fresh or previously frozen $\left(-80^{\circ} \mathrm{C}\right)$ filters were then soaked in $90 \%$ buffered acetone in a centrifuge tube, covered with aluminum foil and placed in a refrigerator overnight. Fluorometer (Turner 10-AU) readings were done before and after acidification $(0.1 \mathrm{M} \mathrm{HCl})$.

Length-weight analyses. The prosome lengths of freshly caught specimens of Oithona similis and Pseudocalanus elongatus were measured as described above. Specimens were quickly rinsed in Milli-Q water or $3 \%$ ammonium formate to remove salts, and placed in an open pre-weighed tin capsule (Klein Breteler et al. 1982, Chisholm \& Roff 1990). Capsule samples containing various numbers of copepodites of a specific stage were prepared. Between 1 to 6 ind. for $P$. elongatus, and 1 to 25 ind. for $O$. similis were pooled for each determination. Stages $\mathrm{C} 1$ to adults for $P$. elongatus, and $\mathrm{C} 2$ to adults for $O$. similis were examined. Prosome lengths of all copepodites within each capsule were measured, and the arithmetic mean applied when determining the length-weight regression. After drying samples at $60^{\circ} \mathrm{C}$ for $24 \mathrm{~h}$, samples were allowed to cool at room temperature for $24 \mathrm{~h}$ in a desiccator before being weighed. The capsules were then analysed for carbon using an Elemental Analyser (Carlo Erba). Length-weight relationships were determined for both species using the equation:

$$
\log _{10} W=a+\left[b\left(\log _{10} L\right)\right]
$$

where $a$ and $b$ are constants, $W$ is carbon mass ( $\mu \mathrm{g} \mathrm{C}$ ) and $L$ is prosome length $(\mu \mathrm{m})$.

Abundance, biomass and adult production rates. To estimate the abundance of the copepods, samples were collected with both a 68 and a $200 \mu \mathrm{m}$ mesh net (mouth diameters of 0.3 and $0.4 \mathrm{~m}$ respectively). Samples were preserved in $4 \%$ formaldehyde solution for later identification in the laboratory using a dissecting microscope. The abundance of all stages of Oithona similis was determined from the analysis of samples from the $68 \mu \mathrm{m}$ mesh net. For Pseudocalanus elongatus, nauplii and $\mathrm{C} 1$ stages were counted from the $68 \mu \mathrm{m}$ mesh net samples, while the abundance of the $\mathrm{C} 2$ to adult stages was derived from the $200 \mu \mathrm{m}$ mesh net. The choice of which net data to apply was made based on an examination of which net gave the greatest abundances of stages (data not shown).

Identification and staging of animals was based on published keys for Pseudocalanus and Oithona (Ogilvie 1953, Sazhina 1985, Frost 1989) including web resources (http://copepodes.obs-banyuls.fr/en). Prosome lengths of copepodite stages were measured using the $68 \mu \mathrm{m}$ mesh samples. The mass of each copepodite stage ( $\mathrm{C} 1$ to adult) was calculated by applying a monthly mean prosome length for each stage to our length-weight equation, and then multiplying this by the stage and sex-specific abundance to determine biomass. Total biomass $\left(B, \mu \mathrm{g} \mathrm{C} \mathrm{m}^{-3}\right.$ ) was obtained by summing all copepodite stages excluding nauplii.

Weight-specific fecundity rates (WSFR, $\mathrm{d}^{-1}$ ) were obtained as:

$$
\mathrm{WSFR}=\mathrm{EPR}_{0-24} \times \frac{W_{\mathrm{e}}}{W_{\mathrm{f}}}
$$

where $W_{\mathrm{e}}$ and $W_{\mathrm{f}}$ are the egg and adult female carbon weights respectively. We applied egg mass C of 0.014 and $0.14 \mu \mathrm{g} \mathrm{C} \mathrm{egg}^{-1}$ for Oithona similis and Pseudo- 
calanus elongatus, respectively, as estimated from egg volume assuming a conversion factor of $0.14 \times 10^{-6} \mu \mathrm{g}$ C $\mu \mathrm{m}^{-3}$ (Kiørboe et al. 1985, Huntley \& Lopez 1992, Uye \& Sano 1995). The adult weights were based on the arithmetic mean lengths of females in the incubation experiments, as predicted by our length-weight equations.

Adult female production rates $\left(\mathrm{PR}, \mu \mathrm{g} \mathrm{C} \mathrm{m}^{-3} \mathrm{~d}^{-1}\right)$ were obtained by multiplying the biomass of adult

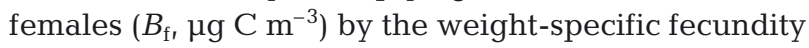
rate (WSFR):

$$
\mathrm{PR}=B_{\mathrm{f}} \times \mathrm{WSFR}
$$

We applied a modified Michaelis-Menten relationship to describe the relationship between egg production rates (EPR, eggs female $\mathrm{e}^{-1} \mathrm{~d}^{-1}$ ) and chl a concentration $\left(\mathrm{mg} \mathrm{m}^{-3}\right)$ (Ward \& Hirst 2007):

$$
\mathrm{EPR}=y_{0}+\frac{a \times(\mathrm{Chl} a)}{b+(\mathrm{Chl} a)}
$$

where $y_{0}$ is the egg production rate when chl $a$ is zero. This equation does not assume that egg production converges at 0 as chl a levels approach 0 .

\section{RESULTS}

Temperature and chl a concentrations varied on a seasonal basis over the course of this investigation (Fig. 2). Temperature was lowest in February and March when surface and bottom waters were $\sim 6^{\circ} \mathrm{C}$. Temperature rose steadily through spring and reached a peak at $16.1^{\circ} \mathrm{C}$ in July. From early July to late Sep- tember, temperatures were between $\sim 12$ and $16^{\circ} \mathrm{C}$. The difference in temperature between surface and bottom waters rarely exceeded $1^{\circ} \mathrm{C}$, although there were isolated instances of a $>2{ }^{\circ} \mathrm{C}$ difference. Temperature fell, starting late September, reaching its minimum once again in February. Chl a demonstrated low values throughout the winter months of November to February, increasing greatly in April to a peak of $10.2 \mathrm{mg} \mathrm{m}^{-3}$. From late May until late October, values rarely fell below $2 \mathrm{mg} \mathrm{m}^{-3}$. A second peak was evident in August, again being $>10 \mathrm{mg} \mathrm{m}^{-3}$.

\section{Egg production}

Copepod egg production rates $\left(\mathrm{EPR}_{0-24}\right)$ varied markedly with season (Figs. 3a \& 4a), with maximum rates in early June for Pseudocalanus elongatus (7.41 eggs female ${ }^{-1} \mathrm{~d}^{-1}$ ) and in July for Oithona similis (4.00 eggs female ${ }^{-1} \mathrm{~d}^{-1}$ ). P. elongatus EPR rose sharply in May, falling back in June, and then somewhat varied over the remainder of the year, but remained $>0.7$ eggs female ${ }^{-1} \mathrm{~d}^{-1}$ until late November. O. similis EPR were greatest in May and July, and stayed $>0.7$ eggs female ${ }^{-1} \mathrm{~d}^{-1}$ from June until November.

Oithona similis annual average $\mathrm{EPR}_{0-24}$ and $\mathrm{EPR}_{24-48}$ values were $1.01( \pm 0.532,95 \% \mathrm{CI})$ and $0.51( \pm 0.337$, $95 \%$ CI) eggs female ${ }^{-1} \mathrm{~d}^{-1}$, respectively (Table 1, Fig. 5). Pseudocalanus elongatus annual average $\mathrm{EPR}_{0-24}$ and $\mathrm{EPR}_{24-48}$ rates were 1.79 and 1.23 eggs female ${ }^{-1} \mathrm{~d}^{-1}$, respectively (Table 1 ). In both species, average rates were lower on the second day of incubation than on the first. However, paired $t$-tests showed

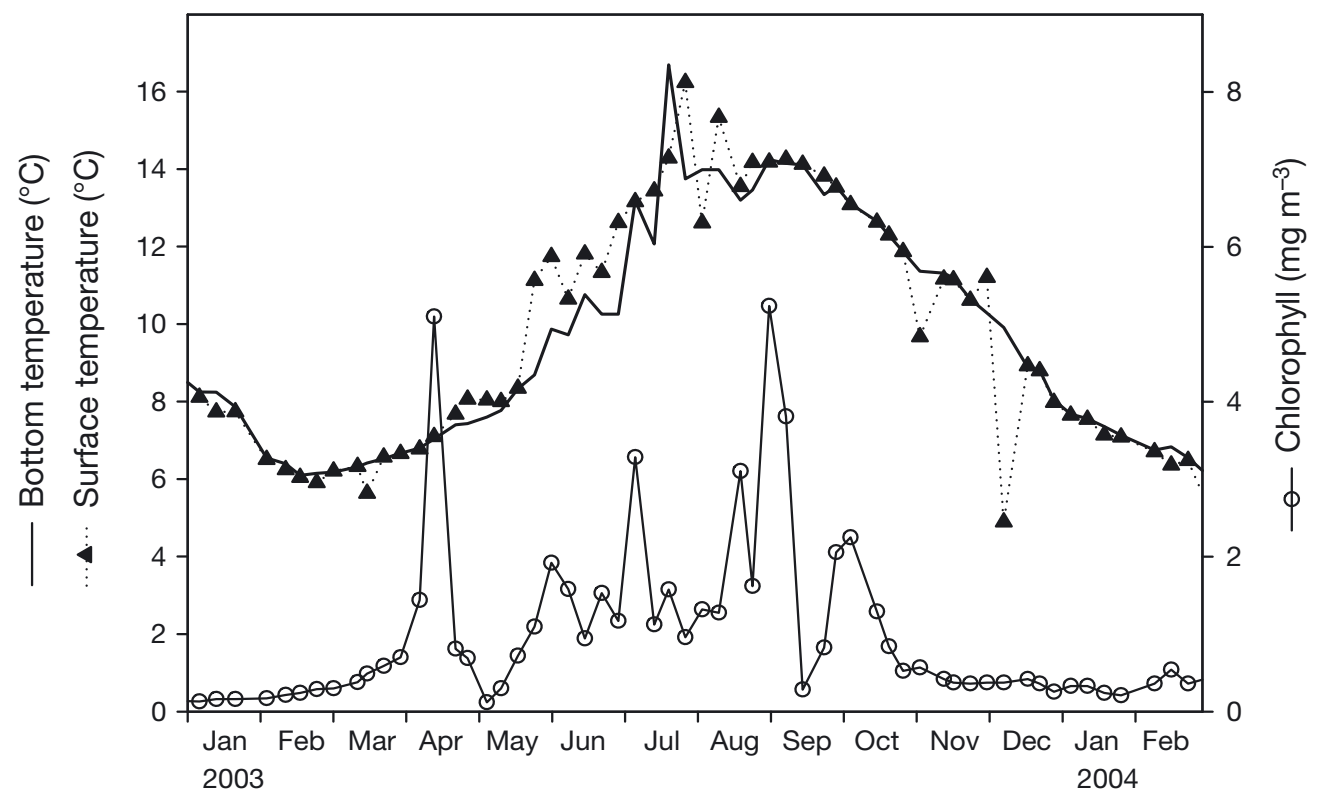

Fig. 2. Surface $(1 \mathrm{~m})$ and bottom $(45 \mathrm{~m})$ water temperature and surface chlorophyll a concentration at the Stonehaven site in the northern North Sea 


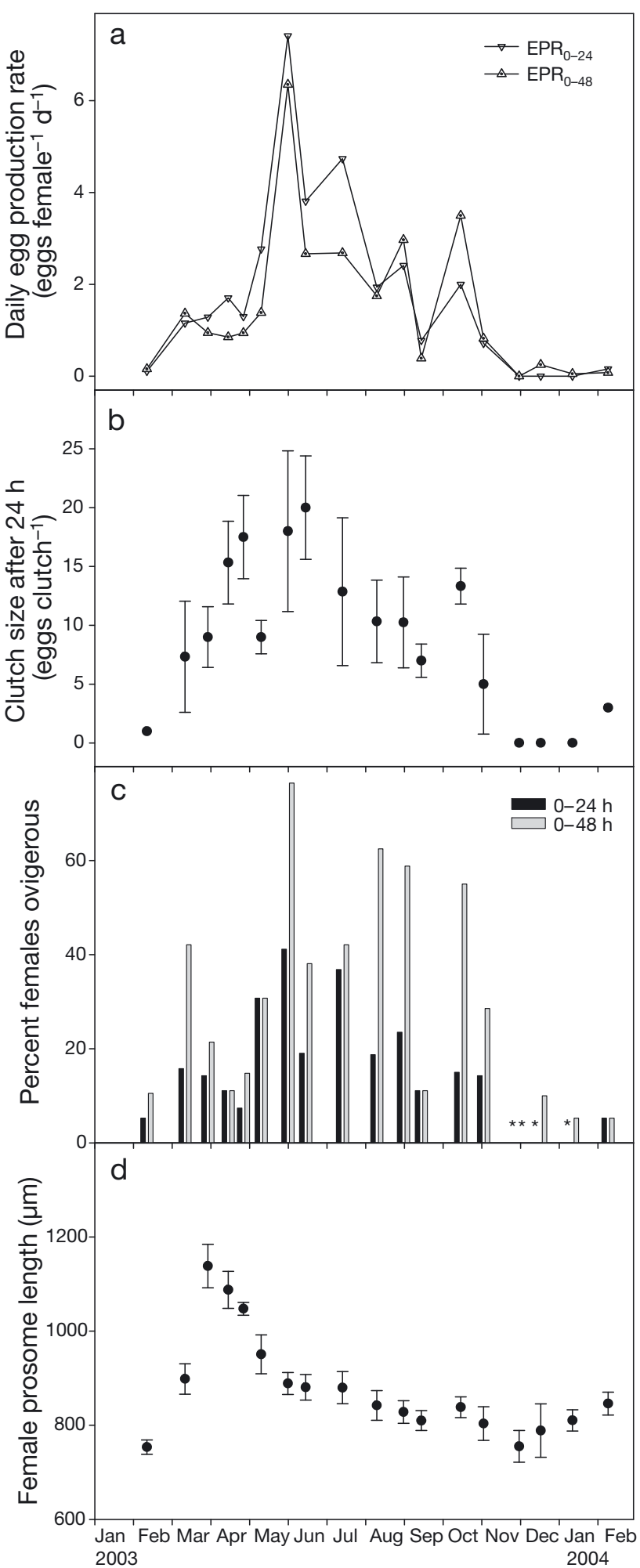

Fig. 3. Pseudocalanus elongatus. (a) Daily egg production rate calculated as $\mathrm{EPR}_{0-24}$ and $\mathrm{EPR}_{0-48 ;}$ (b) clutch size of ovigerous females \pm SD after $24 h_{i}$ (c) proportion of ovigerous females after $24 \mathrm{~h}\left({ }^{*}\right.$ denote a value of 0$)$; and (d) prosome length ( $\mu \mathrm{m}$; $\pm 95 \% \mathrm{CI}$ ) of adult females in the incubation experiment at the Stonehaven site (northern North Sea)

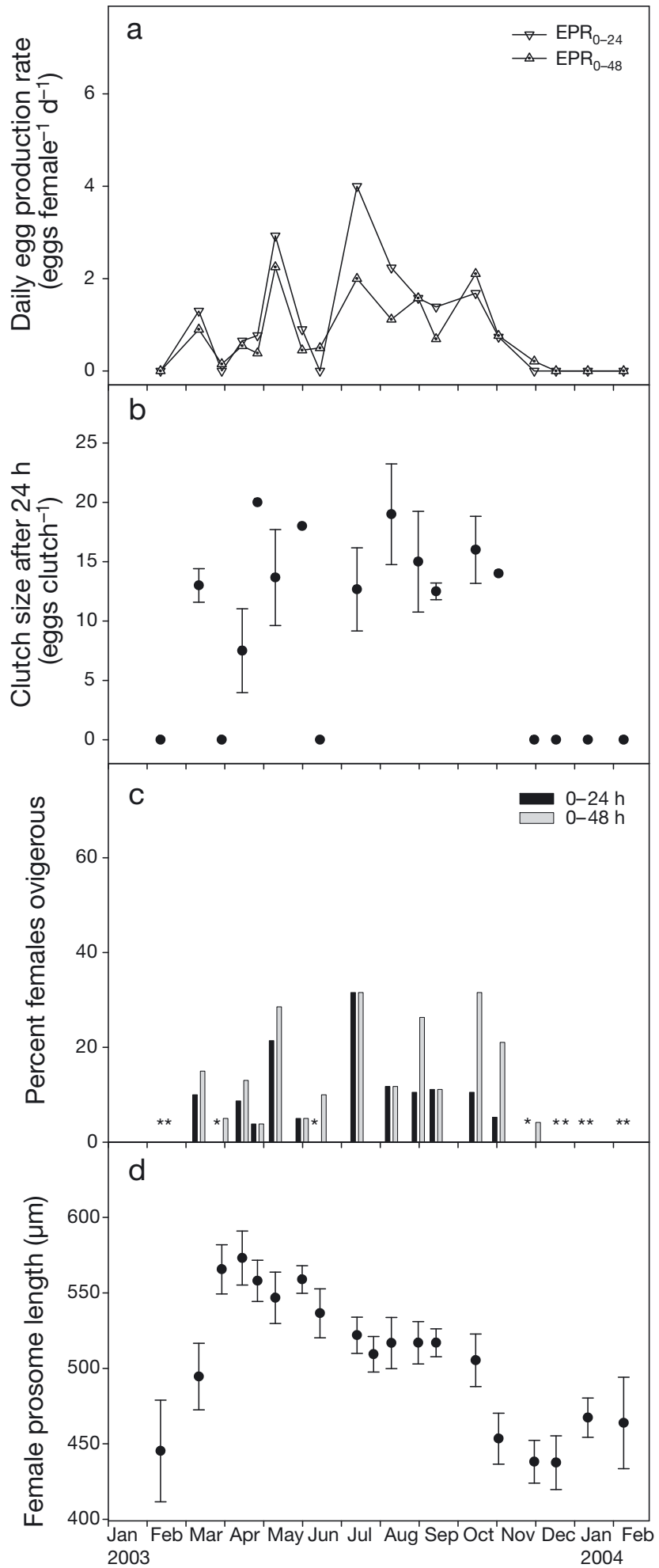

Fig. 4. Oithona similis. (a) Daily egg production rate calculated as $\mathrm{EPR}_{0-24}$ and $\mathrm{EPR}_{0-48 ;}$ (b) clutch size of ovigerous females \pm SD after $24 h_{i}$ (c) proportion of ovigerous females after $24 \mathrm{~h}\left({ }^{*}\right.$ denote a value of 0$)$; and (d) prosome length $(\mu \mathrm{m}$; $\pm 95 \% \mathrm{CI}$ ) of adult females in the incubation experiment at the Stonehaven site (northern North Sea) 
Table 1. Oithona similis and Pseudocalanus elongatus. Comparison of egg production rates $\left(E P R\right.$, eggs female $\left.{ }^{-1} \mathrm{~d}^{-1}\right) \mathrm{for}_{\mathrm{f}}$ incubation method over 0 to $24\left(\mathrm{EPR}_{0-24}\right), 0$ to $48\left(\mathrm{EPR}_{0-48}\right)$ and 24 to $48\left(\mathrm{EPR}_{24-48}\right) \mathrm{h}$, and for the egg-ratio method $\left(\mathrm{EPR}_{\mathrm{p}}\right)$. $\mathrm{n}=18$ paired observations for all methods. ${ }^{*} \mathrm{p}<0.05$; ns: not significant. See Fig. 5

\begin{tabular}{|c|c|c|c|c|c|c|}
\hline \multirow[t]{2}{*}{ Species } & \multirow{2}{*}{$\begin{array}{l}\text { Method } \\
\text { (EPR) }\end{array}$} & \multirow{2}{*}{$\begin{array}{l}\text { Annual mean } \\
\text { (95\% CI) }\end{array}$} & \multirow{2}{*}{$\begin{array}{l}\text { Annual } \\
\text { range }\end{array}$} & \multicolumn{3}{|c|}{ Paired $t$-test comparisons } \\
\hline & & & & $\mathrm{EPR}_{0-48}$ & $\mathrm{EPR}_{24-48}$ & $E P R_{p}$ \\
\hline \multirow[t]{4}{*}{ Oithona similis } & $\mathrm{EPR}_{0-24}$ & $1.01(0.532)$ & $0.00-4.00$ & $0.092 \mathrm{~ns}$ & $0.092 \mathrm{~ns}$ & $0.775 \mathrm{~ns}$ \\
\hline & $\mathrm{EPR}_{0-48}$ & $0.76(0.349)$ & $0.00-2.25$ & - & $0.092 \mathrm{~ns}$ & $0.057 \mathrm{~ns}$ \\
\hline & $\mathrm{EPR}_{24-48}$ & $0.51(0.337)$ & $0.00-2.53$ & - & - & $0.031^{*}$ \\
\hline & $\mathrm{EPR}_{\mathrm{p}}$ & $1.06(0.476)$ & $0.00-3.23$ & - & - & - \\
\hline \multirow[t]{3}{*}{ Pseudocalanus elongatus } & $\mathrm{EPR}_{0-24}$ & $1.79(0.896)$ & $0.00-7.41$ & $0.152 \mathrm{~ns}$ & $0.152 \mathrm{~ns}$ & \\
\hline & $\mathrm{EPR}_{0-48}$ & $1.51(0.752)$ & $0.00-6.35$ & - & $0.152 \mathrm{~ns}$ & \\
\hline & $\mathrm{EPR}_{24-48}$ & $1.23(0.776)$ & $0.00-5.29$ & - & - & \\
\hline
\end{tabular}

no significant differences between $\mathrm{EPR}_{0-24}$ and $\mathrm{EPR}_{24-48}(\mathrm{p}>0.05)$ for both species. EPR of $O$. similis in the egg-ratio method $\left(\mathrm{EPR}_{\mathrm{p}}\right)$ averaged 1.06 eggs female ${ }^{-1} \mathrm{~d}^{-1}( \pm 0.476,95 \% \mathrm{CI})$. Paired $t$-tests indicated $\mathrm{EPR}_{\mathrm{p}}$ to be significantly different from $\mathrm{EPR}_{24-48}(\mathrm{p}=$ 0.031), but not from either $\mathrm{EPR}_{0-24}$ or $\mathrm{EPR}_{0-48}$. Results from the egg-ratio method therefore concurred with those obtained during the first $24 \mathrm{~h}$ of incubation $\left(\mathrm{EPR}_{0-24}\right)$ (Table 1).

The relationship between $\log _{\mathrm{e}} \mathrm{EPR}_{0-24}$ and temperature was significant for Pseudocalanus elongatus ( $\mathrm{p}<$ 0.05), but not for Oithona similis ( $p>0.05)$, while $\log _{e}$ $E P R_{p}$ was significantly related to temperature in O. similis (Fig. 6a,b). Further, the modified MichaelisMenten relationships between both $\mathrm{EPR}_{0-24}$ and $\mathrm{EPR}_{\mathrm{p}}$ and chl $a$ in $O$. similis were significant $(p<0.001)$ (Fig. 6d). The same is true in the case of $\mathrm{EPR}_{0-24}$ in P. elongatus ( $\mathrm{p}<0.001$ ) (Fig. 6c).

\section{Clutch size}

Our incubation results showed that the numbers of eggs in clutches were significantly correlated with the prosome lengths of the female Pseudocalanus elongatus that actually produced the eggs $(p=0.036)$, although the variability explained was very small (an $\mathrm{r}^{2}$ of just 0.088 ; Table 2). The relationship was highly influenced by 4 values measured in the 31st March 2003 sample, which had very low clutch sizes given the prosome length of the females. This may be explained by the fact that temperature was low, food was scarce (chl a concentrations low), and many females had passed through winter conditions. Removing this date resulted in an $\mathrm{r}^{2}$ of 0.294 , which was highly significant $(\mathrm{p}<0.0001)$ (Table 2$)$. Comparing mean clutch sizes with mean prosome lengths of all females (i.e. data in Figs. 3b,d \& 4b,d) over the annual cycle resulted in an insignificant relationship $(p=0.136)$.
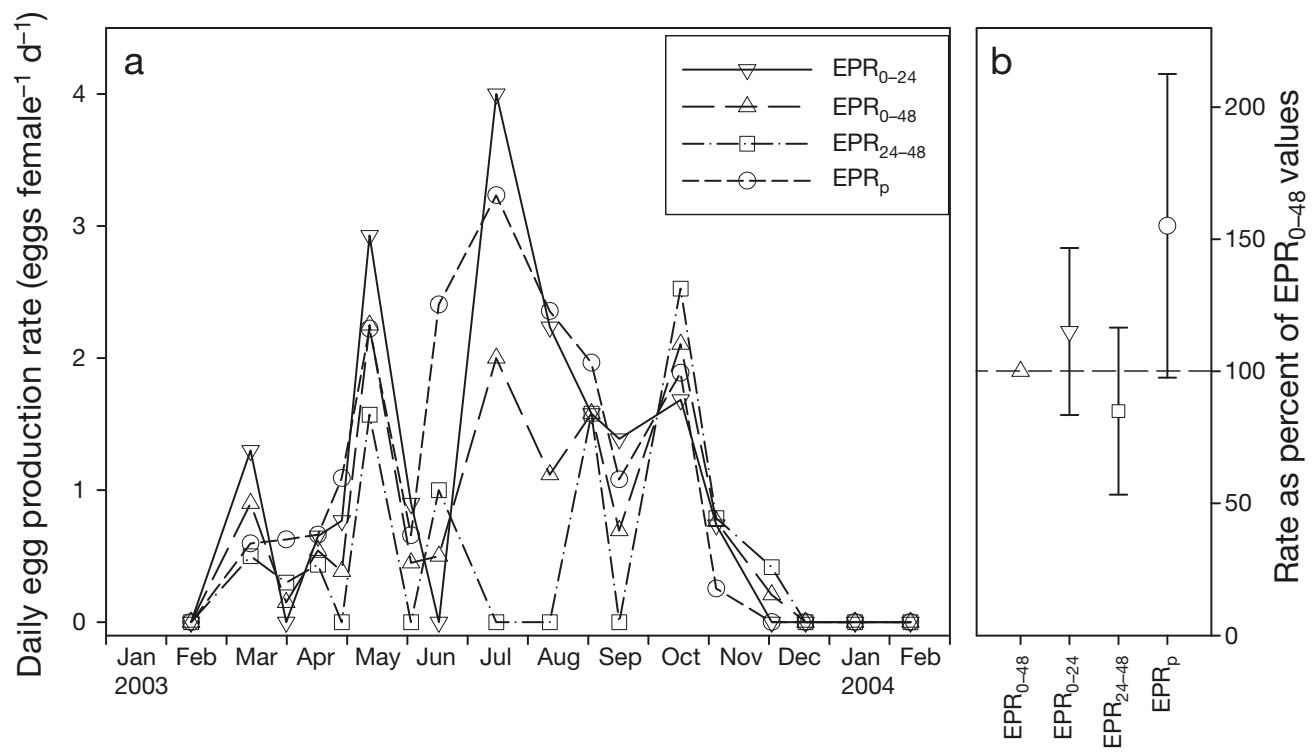

Fig. 5. Oithona similis. Egg production rates (eggs female $\left.{ }^{-1} \mathrm{~d}^{-1}\right)$ obtained from the incubation $\left(\mathrm{EPR}_{0-24}, \mathrm{EPR}_{0-48}\right.$ and $\left.\mathrm{EPR}_{24-48}\right)$ and the egg-ratio method $\left(\mathrm{EPR}_{\mathrm{p}}\right)$ at the Stonehaven site. (a) Rates plotted over the annual sampling period, (b) rates expressed as a percentage of the $\mathrm{EPR}_{0-48}$ values $( \pm 95 \% \mathrm{CI})$ 


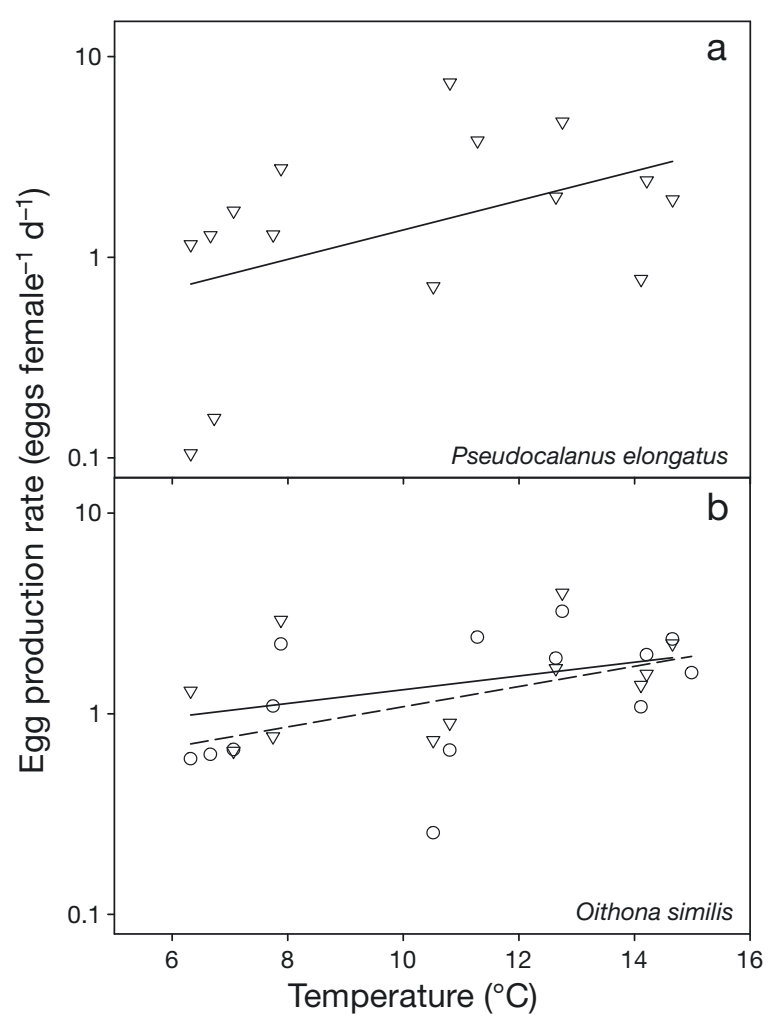

$$
\begin{array}{|lll}
\hline \multicolumn{2}{l}{\text { Pseudocalanus elongatus: }} \\
\rightarrow \quad \log _{\mathrm{e}} \mathrm{EPR}_{0-24}=(0.169 T)-1.376 & {\left[\mathrm{r}^{2}=0.216, \mathrm{p}<0.05\right]} \\
\nabla \quad \mathrm{EPR}_{0-24}=-4.141+\frac{8.084 \times \mathrm{Chl} \mathrm{a}}{0.217 \times \mathrm{Chl} a} & {\left[\mathrm{r}^{2}=0.659, \mathrm{p}<0.001\right]} \\
\text { Oithona similis: } & \\
\nabla \quad \log _{\mathrm{e}} \mathrm{EPR}_{0-24}=(0.079 T)-0.512 & {\left[\mathrm{r}^{2}=0.173, \mathrm{p}<0.05 \mathrm{~ns}\right]} \\
\rightarrow-\log _{\mathrm{e}} \mathrm{EPR}_{\mathrm{p}}=(0.116 T)-1.077 & {\left[\mathrm{r}^{2}=0.256, \mathrm{p}<0.05\right]} \\
\rightarrow \quad \mathrm{EPR}_{0-24}=-0.471+\frac{2.076 \times \mathrm{Chl} a}{0.243 \times \mathrm{Chl} a} & {\left[\mathrm{r}^{2}=0.489, \mathrm{p}<0.001\right]} \\
-\quad \mathrm{EPR}_{\mathrm{p}}=-3.741+\frac{5.669 \times \mathrm{Chla}}{0.101 \times \mathrm{Chla}} & {\left[\mathrm{r}^{2}=0.662, \mathrm{p}<0.001\right]} \\
\hline
\end{array}
$$

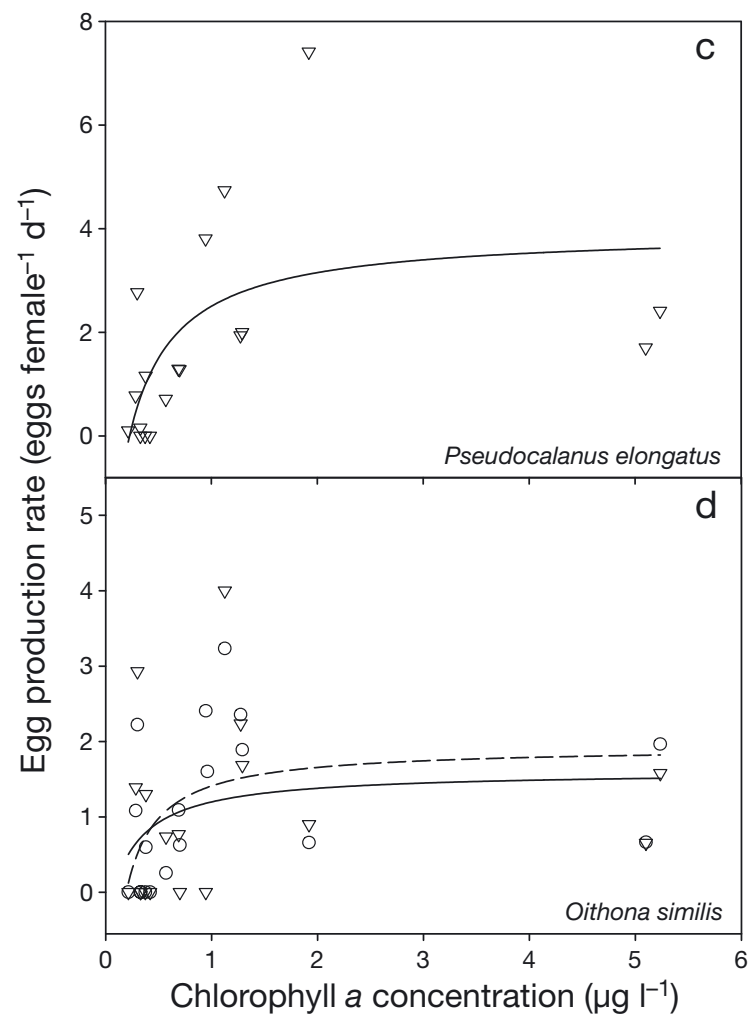

Fig. 6. Pseudocalanus elongatus and Oithona similis. Egg production rates versus $(\mathrm{a}, \mathrm{b})$ temperature and $(\mathrm{c}, \mathrm{d})$ chlorophyll a concentration. Triangles and solid lines denote $\mathrm{EPR}_{0-24}$ data, circles and broken lines denote $\mathrm{EPR}_{\mathrm{p}}$ data

Table 2. Pseudocalanus spp. Comparison of the relationships between clutch size $(C$, eggs) and prosome length $(L, \mu m)$. Values from this study are compared with published equations. Relationships are presented for this study with and without including the data from March 31 (see text for details). ${ }^{*} \mathrm{p}<0.05,{ }^{* *} \mathrm{p}<0.01$; ns: not significant

\begin{tabular}{|c|c|c|c|c|c|c|}
\hline Species & Condition & Relationship & $\mathrm{p}$ & $r^{2}$ & $\mathrm{n}$ & Source \\
\hline \multicolumn{7}{|c|}{ Clutch producing females } \\
\hline P. elongatus & Without 31 March & $C=0.0000436 L^{1.847}$ & $<0.0001^{* *}$ & 0.29 & 46 & Present study \\
\hline P. elongatus & With 31 March & $C=0.02 L^{0.940}$ & $0.036^{*}$ & 0.09 & 50 & Present study \\
\hline \multicolumn{7}{|c|}{ All females over seasonal cycle } \\
\hline P. elongatus & - & $C=0.0016 L^{1.291}$ & $0.136 \mathrm{~ns}$ & 0.16 & 15 & Present study \\
\hline \multicolumn{7}{|c|}{ Published relationships } \\
\hline P. mimus & - & $C=18.17+50.56 \times \ln (L / 1000)$ & $<0.001^{* *}$ & 0.347 & - & Napp et al. (2005) \\
\hline P. newmani & - & $C=29.81+63.62 \times \ln (L / 1000)$ & $<0.001^{* *}$ & 0.595 & - & Napp et al. (2005) \\
\hline P. newmani & - & $C=22.391(L / 1000)^{3.562}$ & $<0.001^{* *}$ & 0.903 & 7 & Ban et al. (2000) \\
\hline P. minutus & - & $C=19.35(L / 1000)^{3.939}$ & - & 0.951 & - & McLaren (1963) \\
\hline Pseudocalanus sp. & - & $C=0.040 L-19.1$ & $<0.0001^{* *}$ & 0.66 & - & $\begin{array}{l}\text { Hopcroft \& } \\
\text { Kosobokova (2010) }\end{array}$ \\
\hline
\end{tabular}


The mean clutch size of Pseudocalanus elongatus had a clear seasonal cycle (Fig. 3b), generally increasing from 1 egg clutch ${ }^{-1}$ in February to 20 eggs clutch ${ }^{-1}$ in June, the maximum size observed being 28 eggs (Table 3). Mean clutch size then decreased with time after June, except for a somewhat higher mean value of 13.3 in October.

In $8.3 \%$ of cases, individual Oithona similis only produced 1 sac during their incubation, in which cases we reported the clutch size from this single egg sac. $O$. similis did not produce eggs from late November through February; during the rest of the year, there was no clear seasonal pattern in the number of eggs in the clutches produced (Fig. 4b). The average size of the clutch ranged from 7.5 to 20.0 eggs clutch $^{-1}$. The relationship between clutch size and prosome length in O. similis was not significant either when assessed by examining those females that actually produced the clutches in incubations ( $p=0.772$ ), or by examining the mean size of females (regardless of whether they produced a clutch or not) against mean clutch size ( $p=$ 0.601).

\section{Ovigerous females}

The highest number of ovigerous females after $24 \mathrm{~h}$ of incubation occurred in May for Pseudocalanus elongatus, and in July for Oithona similis (Figs. 3c \& 4c). The percentage of ovigerous females was highly correlated with $\mathrm{EPR}_{0-24}$ in both P. elongatus $\left(\mathrm{r}^{2}=0.832, \mathrm{p}<\right.$ $0.0001)$ and $O$. similis $\left(\mathrm{r}^{2}=0.958, \mathrm{p}<0.0001\right)$, while no significant relationship was noted between clutch size and $\mathrm{EPR}_{0-24}$ in both species.

\section{Prosome length and length-weight relationship}

Seasonal changes in the prosome lengths of both Pseudocalanus elongatus and Oithona similis were observable at the Stonehaven site (Figs. 3d \& 4d, respectively), with lengths changing by $>25 \%$ over the year in both species. The small adults that were present in February 2003 were likely to be individuals that survived the winter (and which were in effect produced around the late-autumn period of the previous year). The rapid increase in prosome length that was observed in February to March might be due to the recruitment of a new generation, which could have developed in the cold temperatures recorded in these early months (there were nauplii and copepodites in this period, confirming recruitment, see Figs. $7 \&$ 8). The decline in prosome lengths from April until June/ July was likely caused by continual recruitment of smaller adults, which probably developed at warmer

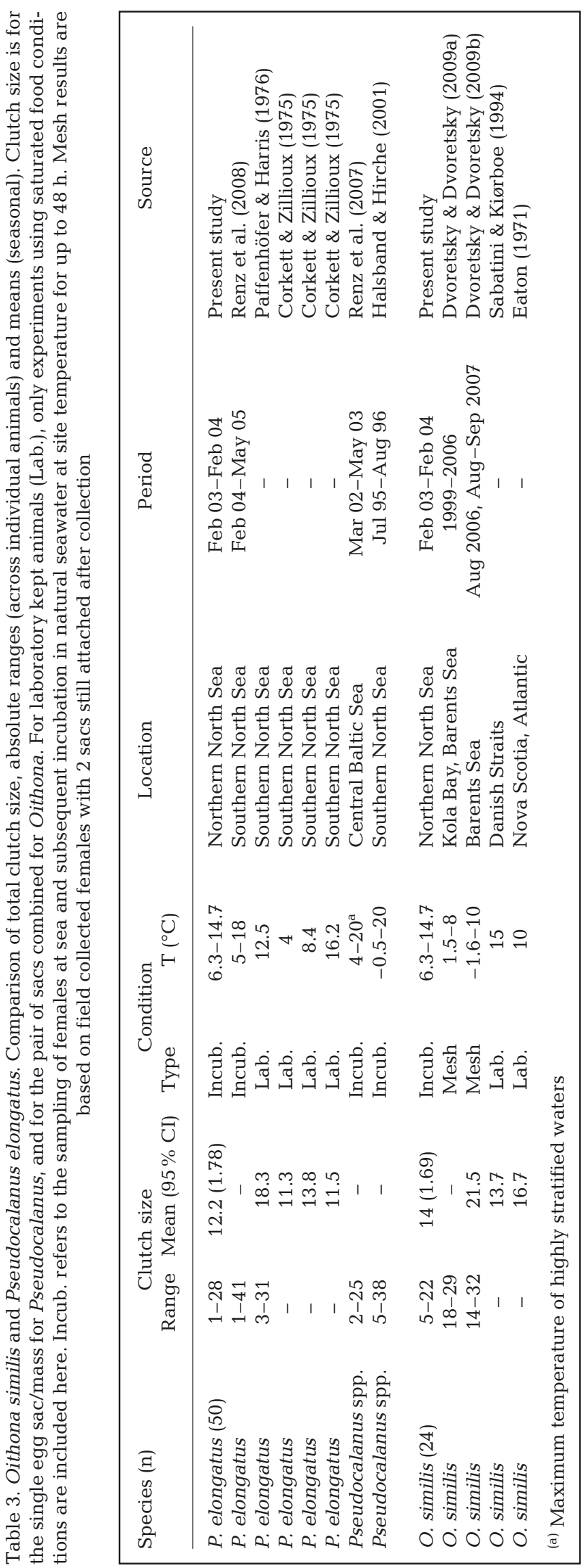


temperatures (Fig. 2). Between June and October, sizes varied little, but declined sharply again in late October in Oithona. This sharp decline might partly be related to poor feeding and the highest temperatures in the preceding month, i.e. September, when some of these adults might have been developing as juveniles. Although there was also a slight decline in prosome length in October to November in Pseudocalanus, this was not as dramatic as in Oithona.

The length-weight regressions for Oithona similis and Pseudocalanus elongatus were highly significant $(p<0.0001)$. Our values are very similar to published

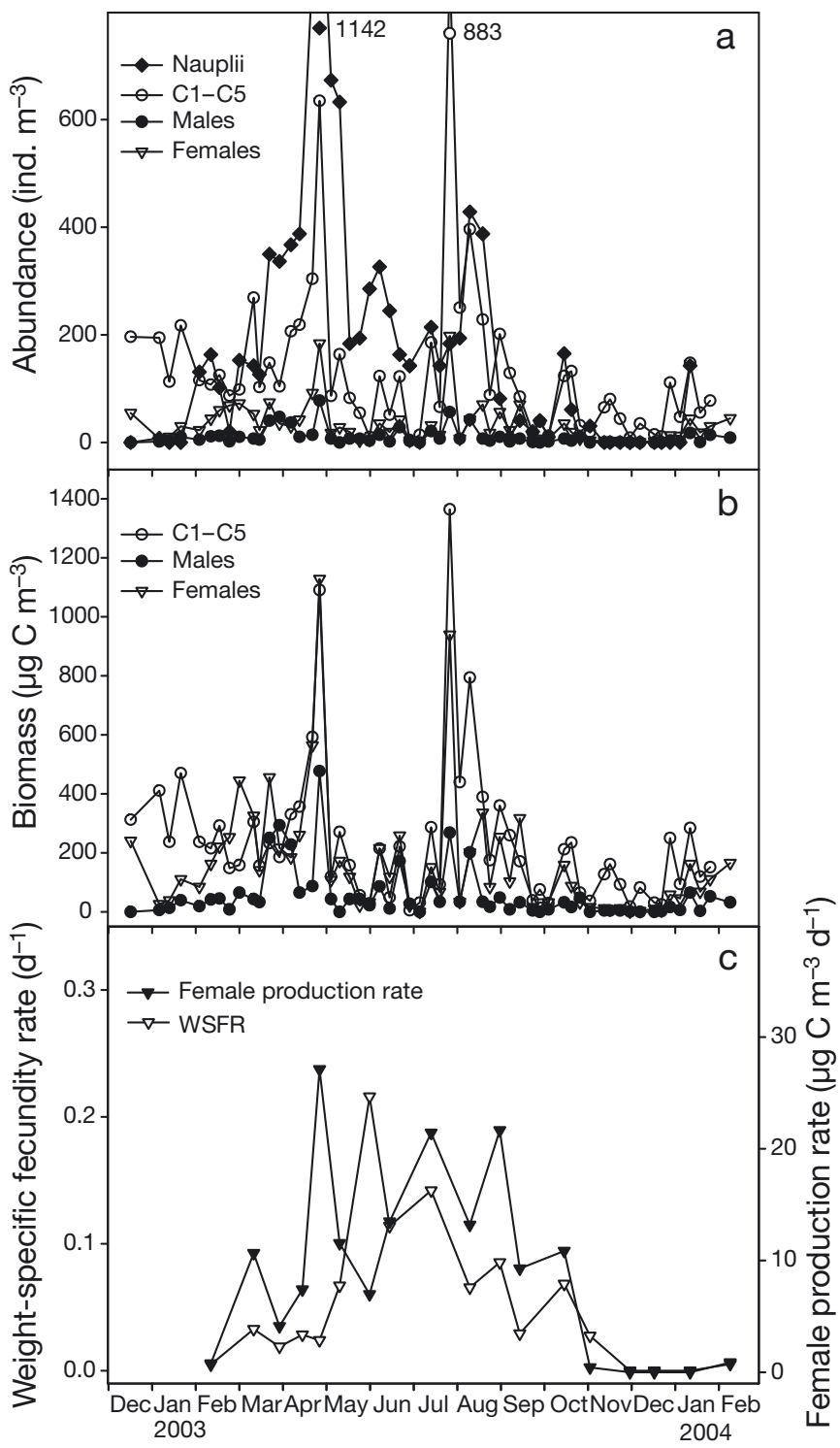

Fig. 7. Pseudocalanus elongatus. (a) Abundance of nauplii, copepodites (C1-C5), and adult females and males; (b) biomass of copepodites (C1-C5), and adult males and females, and (c) production rate and weight-specific fecundity rate (WSFR) of adult females over the period Dec 2002 to Feb 2004 at Stonehaven length-weight regressions (Pseudocalanus spp.: Klein Breteler et al. (1982), Hay et al. (1988) and Liu \& Hopcroft (2008); Oithona similis: Uye (1982) and Sabatini \& Kiørboe (1994).

\section{Abundance, biomass and weight-specific fecundity rates}

Pseudocalanus elongatus density (nauplii to adults inclusive) ranged between 9 and 2039 ind. $\mathrm{m}^{-3}$ over the period of study (Fig. 7a). Copepodite density ( $\mathrm{C} 1$ to

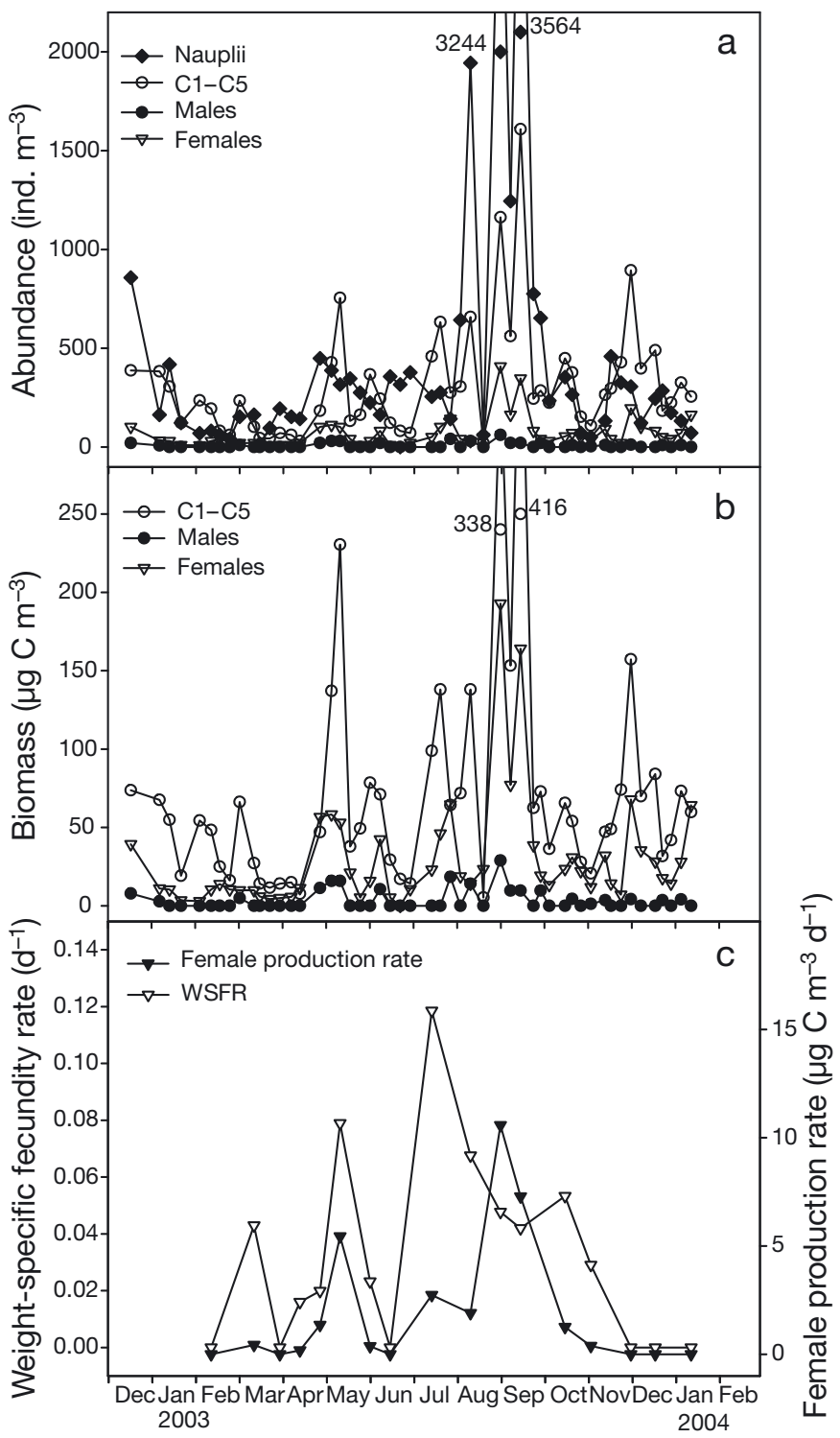

Fig. 8. Oithona similis. (a) Abundance of nauplii, copepodite (C1-C5), and adult females and males; (b) biomass of copepodites (C1-C5), and adult females and males, and (c) production rate and weight-specific fecundity rate (WSFR) of adult females over the period Dec 2002 to Jan 2004 at Stonehaven 
adults inclusive) ranged between 9 and 1138 ind. $\mathrm{m}^{-3}$, and $\mathrm{C} 1$ to adult biomass between 19 and $2696 \mu \mathrm{g} \mathrm{C} \mathrm{m}{ }^{-3}$ (Fig. 7b). A peak in the biomass of copepodites and females was noted at the end of April, with a second peak in July. The maximum adult female production rate $\left(27.1 \mu \mathrm{g} \mathrm{C} \mathrm{m}{ }^{-3} \mathrm{~d}^{-1}\right.$; Fig. $\left.7 \mathrm{c}\right)$ occurred at the end of April, with secondary peaks in production occurring in July and September. The weight-specific fecundity rate reached its maximum of $0.22 \mathrm{~d}^{-1}$ in early June, with rates exceeding $0.1 \mathrm{~d}^{-1}$ from May to July. Adult males were typically less abundant than adult females, with a sex ratio (male:female) across all sampling dates of $0.40( \pm 0.37 \mathrm{SD})$.

The density of Oithona similis ranged between 73 and 5540 ind. $\mathrm{m}^{-3}$ (Fig. 8a). Copepodite (C1 to adults inclusive) density was between 51 and 1975 ind. $\mathrm{m}^{-3}$. Biomass (Fig. 8b) reached a maximum of $590 \mu \mathrm{g} \mathrm{C}$ $\mathrm{m}^{-3}$ in September. The maximum weight-specific fecundity rate was noted in July $\left(0.12 \mathrm{~d}^{-1}\right)$, and rates exceeded $0.02 \mathrm{~d}^{-1}$ from May until October (except on a single date in June when values were very low). Production rates of adult females showed a first peak in May (5.4 $\mu \mathrm{g} \mathrm{C} \mathrm{m}^{-3} \mathrm{~d}^{-1}$ ) and maximum values in early September $\left(10.6 \mathrm{\mu g} \mathrm{C} \mathrm{m}^{-3} \mathrm{~d}^{-1}\right)$. Adult males were much less abundant than adult females, with a mean sex ratio (male:female) across all sampling dates of $0.11( \pm 0.19 \mathrm{SD}$; male abundance never exceeded 61.2 ind. $\mathrm{m}^{-3}$.

The biomass of Oithona similis (Fig. 8b) was lower than that of Pseudocalanus elongatus (Fig. 7b). In contrast, $P$. elongatus was commonly less abundant, these differences being a consequence of the much smaller body size of $O$. similis. Both species had lower overall biomass during parts of May and June compared to the other spring and summer months. Adult female production rates in both species were rather variable over the course of the year, but highest in May and September in O. similis, and highest in April and then from June to September in $P$. elongatus. The production rates of females did not always closely follow the seasonal pattern in weight-specific fecundity rates, this mismatch being a result of the great variability in adult female abundance and biomass (production being the product of biomass and weight-specific fecundity).

\section{DISCUSSION}

\section{Egg production}

In this study, the EPR of Pseudocalanus elongatus $\left(E P R_{0-24}\right)$ reached a maximum of 7.4 eggs female ${ }^{-1} \mathrm{~d}^{-1}$. This is comparable to the maximum of 8 eggs female ${ }^{-1}$ $\mathrm{d}^{-1}$ found for Pseudocalanus spp. at Helgoland Roads in the North Sea (Halsband \& Hirche 2001), and a maximum of 9.1 eggs female ${ }^{-1} \mathrm{~d}^{-1}$ in the southern North Sea (Renz et al. 2008). Halsband \& Hirche (2001) found that egg production largely ceased between December and January, and we observed little to no egg production between December and February at our more northerly location. The range of average Oithona similis EPR we observed (0 to 4.0 eggs female ${ }^{-1} \mathrm{~d}^{-1}$ ) are comparable to literature data (Table 4). For example, in various locations in the North Sea, Nielsen \& Sabatini (1996) found that rates of Oithona sp. egg production in spring ranged from 0.83 to 5.65 eggs female ${ }^{-1} \mathrm{~d}^{-1}$.

The $\mathrm{EPR}_{0-24}$ values for Pseudocalanus elongatus were significantly correlated with temperature in our study (Fig. 6). This was not the case in Oithona similis, although the egg-ratio method results were significantly correlated with temperature. Comparisons over a wider range of temperatures and environments suggest that temperature has an important control on Oithona EPR (Ward \& Hirst 2007, see their Fig. 6), and the EPR we observed fell close to the global temperature-dependent patterns previously reported for this genus (Ward \& Hirst 2007). However, when one examines just a narrow temperature range, the variability resulting from seasonal changes in food or other conditions may be too large to observe any significance.

Our results demonstrated a significant relationship between Pseudocalanus egg production and chl $a_{\text {, }}$ with patterns being very similar to those found in the global synthesis of these rates in Pseudocalanus spp. by Bunker \& Hirst (2004). These authors found no significant relationship for Oithona spp. egg production versus chl $a$ when using a Michaelis-Menten relationship. In contrast, in the current study, we used the modified equation and found the relationship to be significant. Interestingly, Ward \& Hirst (2007) also reported a significant relationship between EPR and chl a for $O$. similis in the Scotia Sea using the same equation used here. We suggest this modified Michaelis-Menten equation is a better approach to describing egg production as it allows for a nonzero 0 intercept, i.e. the consumption of non-chlorophyll bearing prey fueling egg production. This is common in Oithona similis (Nakamura \& Turner 1997) and in Oithona spp. more generally (see review in Castellani et al. 2008).

The significant correlation between the percentage of ovigerous females and the $\mathrm{EPR}_{0-24}$ as well as the insignificant relationship between clutch size and $\mathrm{EPR}_{0-24}$ in both Pseudocalanus elongatus and Oithona similis suggest that changes in the percentage of ovigerous females may be more important in driving changes in $\mathrm{EPR}_{0-24}$ for these species in the northern North Sea. 


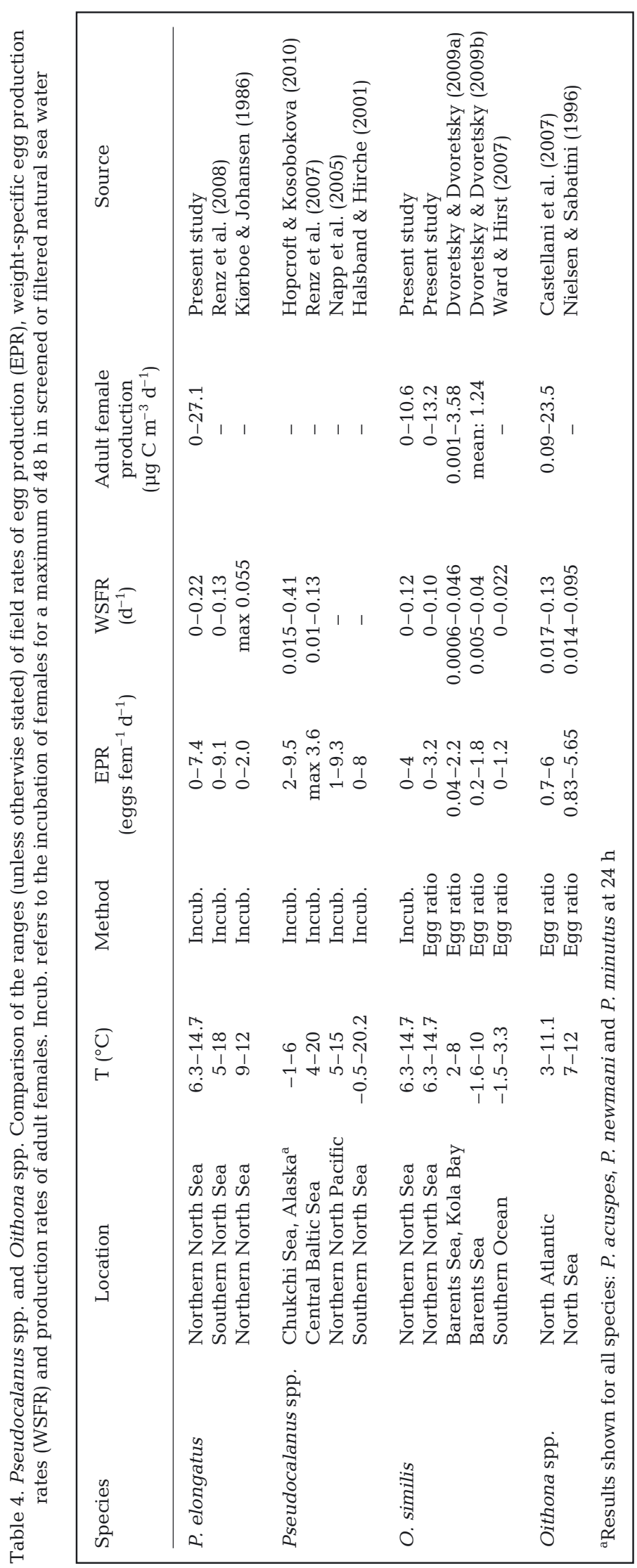

\section{Comparing egg production methods}

Our results are the first to directly compare these 2 commonly applied egg production methods. Egg-ratio method $\left(\mathrm{EPR}_{\mathrm{p}}\right)$ results for Oithona similis did not significantly differ from $\mathrm{EPR}_{0-24}$ or $\mathrm{EPR}_{0-48}$ incubations. However, they were significantly different from $\mathrm{EPR}_{24-48}$ values (paired $t$-tests, Table 1). The egg-ratio method produced the highest rates on average, with the lowest rate being from $\mathrm{EPR}_{24-48}$.

Results from incubations for the 3 different periods $(0-24,24-48$ and $0-48 \mathrm{~h})$ were not significantly different from one another in either Pseudocalanus elongatus or Oithona similis, although rates were on average lower on the second day $(24-48 \mathrm{~h})$ than on the first $(0-24 \mathrm{~h})$. Hopcroft \& Kosobokova (2010) incubated several species of Pseudocalanus in the sub-Arctic Chukchi Sea, and found a significant reduction in EPR between the first and second day of incubation. In their study, and in ours, females were incubated individually in $70 \mathrm{ml}$ tissue culture flasks. This leads to the question: might food be significantly reduced during incubations when using such volumes? A comparison of published clearance rates for Oithona and Pseudocalanus shows that rates typically vary between $\sim 2$ to $10 \mathrm{ml}$ ind. $^{-1} \mathrm{~d}^{-1}$ for Oithona spp. (Lampitt and Gamble 1982, White \& Roman 1992, Nakamura \& Turner 1997, Svensen \& Kiørboe 2000), and from 3 to $95 \mathrm{ml}$ ind..$^{-1} \mathrm{~d}^{-1}$ in $P$. elongatus (Paffenhofer \& Turner 1976, Koski et al. 1998, Schultz \& Kiørboe 2009). It seems likely that $<30 \%$ of the food may be cleared in $48 \mathrm{~h}$ by Oithona at temperatures similar to that in our study, while the maximum clearance of Pseudocalanus suggests that a much greater proportion of the food could be cleared. Combining this fact with the apparent reduction in EPR with time (albeit this was not significant in our study), we recommend that larger volumes be used for these species in future studies, especially if the incubation period exceeds $24 \mathrm{~h}$.

Both the egg-ratio and incubation methods have problems. Incubations involve containment, which can change vertical migration ambits, diel feeding and the food regime with time, as well as the turbulence experienced. This is important as Oithona, unlike many calanoids, does not create feeding currents (Paffenhöfer 1993). It is a raptorial ambush feeder in which levels of turbulence can impact feeding rates (Saiz et al. 2003). While the egg-ratio method overcomes many of the concerns with incubations, it requires accurate collection of adults and eggs, their correct identifi- 
cation, and is generally more time consuming. Fortunately, Oithona spp. egg sacs were relatively easy to recognise, and typically do not break apart at collection (authors' pers. obs.). However, in other species, the sac may be too fragile or conspecifics may be too difficult to differentiate. Pseudocalanus elongatus eggs can be easily dislodged from the egg mass (authors' pers. obs.), and there is no true egg sac membrane. Thus, we did not apply the egg-ratio method to this species in our study.

The female copepods' feeding history prior to capture can determine egg laying rate in the first $24 \mathrm{~h}$ of incubation (e.g. Plourde \& Runge 1993), and this incubation period is often selected when studying broadcast spawners collected from the wild. However, for egg carrying copepods, the inter-clutch time should also be considered (Hirst \& McKinnon 2001). Females that are free of egg sacs are usually selected for incubations. Incubations will include both females that are between clutches at the time of collection, and those females that have lost their eggs during the net collection. The 2 groups will be at different stages in their reproductive cycles, the latter group being likely unable to produce another batch for a considerable period. Extending the incubation period for sac spawners partly counters this problem. Clearly, there should be a balance between incubating for a long enough period to ensure clutches are produced, and minimising incubation artefacts. The lack of any significant difference between $\mathrm{EPR}_{0-24}$ and $\mathrm{EPR}_{\mathrm{p}}$ in Oithona gives us confidence that $24 \mathrm{~h}$ incubations were sufficient in this study. The lower average $\mathrm{EPR}_{24-48}$ indicates that care needs be taken when incubating animals for $>24 \mathrm{~h}$.

\section{Clutch size and prosome length}

The average clutch size in Pseudocalanus elongatus in the first $24 \mathrm{~h}$ of incubation ranged between 1 and 28 eggs (egg mass) $)^{-1}$ in the present study. Other North Sea studies have reported clutch sizes to vary between 5 and 38 (Halsband \& Hirche 2001) and 1 to 41 (Renz et al. 2008) (Table 3). There was a clear seasonal signal in the clutch size of $P$. elongatus in our study, which increased through much of February to June and then declined until November. Clutch size in Oithona similis had no clear seasonal pattern at Stonehaven, other than being 0 from late December until February, and then $>11$ eggs clutch ${ }^{-1}$ through much of the remainder of the year (Fig. $4 \mathrm{~b}$ ). The relationship between clutch size $(C)$ and prosome length $(L)\left(C=a L^{\mathrm{b}}\right)$ was not significant in this species when assessed by examining either those females that actually produced the clutches in incubations, or the mean size of females (regardless of whether they produced a clutch or not) against mean clutch size over the course of the study.

The body size of ectotherms (including copepods) has been shown to be related to developmental temperature (temperature size rule; Atkinson 1994), and to a lesser extent to food (Vidal 1980, Dam \& Peterson 1991); higher temperatures and lower food concentrations both result in smaller adults. Temperature during development and the changing pattern of recruitment to the adult stage may explain much of the observed change in prosome length over the year. This has additional importance as clutch sizes and reproductive effort have also often been linked to adult female size. A comparison between published relationships between clutch size and prosome length in Pseudocalanus are given in Table 2. Corkett \& McLaren (1969) found the total volume and/or number of eggs in Pseudocalanus spp. clutches to be highly predictable from the female size. Halsband \& Hirche (2001) found at the Helgoland Roads site in the North Sea, that the majority of the seasonal variation in mean clutch size (and egg production) over their year long study was explained by changes in mean prosome length in the broadcast spawners Acartia clausi, Temora longicornis and Centropages hamatus. This is an important outcome, suggesting that adult body size is critical to clutch size changes. In the same study, the amount of variability explained by changes in mean prosome length in Pseudocalanus was much lower $\left(\mathrm{r}^{2}=0.247\right)$, although still significant. When clutch size was related to female prosome length, the relationship somewhat varied across studies (Table 2), with $\mathrm{r}^{2}$ values varying from 0.09 to 0.951 . However, samples spanning the entire year were included only in Halsband \& Hirche (2001), Napp et al. (2005), and the present study. These are also the studies that show a comparatively lower explained variance. While we found a significant relationship when we considered only those females that produced the clutch (Table 2), little of the variation was explained by changes in mean prosome length $(<9 \%)$, and this relationship improved when we considered other seasonal factors and removed early season data (variation explained then became $29 \%$ ). This might be because in seasonal studies, females in autumn and spring may have similar sizes, but experience vastly different food quantities and qualities. In addition, mean prosome lengths are the product of various overlapping generations and of adults of different ages. The age of an adult has a profound impact on its EPR (Kimoto et al. 1986). Neither the study of Halsband \& Hirche (2001) nor ours support body size as the primary driver of clutch size or EPR in Pseudocalanus in the North Sea, and our study further demonstrate the lack of importance of body size in Oithona. It is interesting that the broadcast spawners in Halsband \& 
Hirche (2001) produced strong relationships, while the sac spawners did not. Whether these differences are genuinely related to the spawning strategies is not clear at this stage.

Although we found that clutch size generally increased with chl a and then leveled off in Pseudocalanus elongatus, there was no clear pattern in Oithona similis. Ward \& Hirst (2007) also found no observable relationship between clutch size and chl $a$ in $O$. similis across the Scotia Sea. Oithona are omnivorous species, and microzooplankton can play a greater role in their diets (Castellani et al. 2008), which may explain the lack of a relationship. Hopcroft \& Roff's (1996) study on various species of egg carrying copepods in tropical waters also found no significant difference in clutch sizes between locations with contrasting chl a concentrations. Although food levels can impact overall EPR in egg carriers, this may act in Oithona primarily by altering the interval at which clutches are produced and the numbers of ovigerous females, rather than through clutch size itself.

\section{Ovigerous females}

The maximum number of ovigerous Oithona similis females found at Stonehaven was $32 \%$, which compares well with the value of 23 to $41 \%$ in the Barents Sea (Dvoretsky \& Dvoretsky 2009a). In the Southern Ocean, Ward \& Hirst (2007) found that the proportion of females of $O$. similis carrying eggs varied from 0 to $67 \%$, but with most values falling between 20 and $40 \%$. Castellani et al. (2007) found that from 33 to $82 \%$ of females were ovigerous across spring and summer in the Irminger Sea in the northwestern Atlantic. We need to emphasise that while the ovigerous population was defined in the present study as that which produced eggs within $24 \mathrm{~h}$, this was determined directly from the egg sacs collected using nets in Castellani et al. (2007), Ward \& Hirst (2007), and Dvoretsky \& Dvoretsky (2009a). The percentage of ovigerous females obtained from preserved net samples is the result of the balance between those females that were incapable of producing eggs at all, those females that were actively reproducing and were carrying a clutch, and those females that were actively reproducing but were between clutches. In contrast, the balance between these when incubating females, especially given the synchronised nature of incubating non-egg bearing females to begin an experiment, means that a different balance of egg carrying (ovigerous) females may be reached after incubating for 24 or $48 \mathrm{~h}$. Comparisons between percentages of ovigerous females from incubations versus fixed net samples are therefore not straightforward.
On $8.3 \%$ of occasions in our incubations, individual females of Oithona similis produced a single egg sac. Sabatini \& Kiørboe (1994) reported a comparable value of $10 \%$. An assumption of 2 egg sacs female ${ }^{-1}$ is commonly made when reconstructing data using the eggratio method. This is necessary because egg sacs commonly become detached during sampling. Although this is a potential problem with the egg-ratio method (since net samples are in effect used to determine the numbers of egg sacs and the numbers of females these sacs are attributable to, the usual assumption being that each female has produced 2 sacs), it only impacts estimates of the number of ovigerous females and not the average EPR.

In Pseudocalanus elongatus, the maximum percentage of ovigerous females was much greater than was achieved in Oithona similis, being $>40 \%$ after $24 \mathrm{~h}$ of incubation and $75 \%$ after $48 \mathrm{~h}$ in late May. Our values are broadly similar to those observed by Halsband \& Hirche (2001) for Pseudocalanus spp. at the Helgoland Roads site in the North Sea, and by Renz et al. (2008) for Pseudocalanus elongatus in the southern North Sea (they observed that the percentage of ovigerous females after $24 \mathrm{~h}$ of incubation was typically between $\sim 10$ and $40 \%$ ). Our results show that using a $24 \mathrm{~h}$ incubation period commonly gives a much lower value for the percentage of ovigerous females than using a $48 \mathrm{~h}$ incubation period, with $48 \mathrm{~h}$ values being $>3 \times$ of the values after $24 \mathrm{~h}$. As already discussed, incubation approaches may present a problem when determining the percentage of ovigerous females in a natural population.

\section{Biomass, weight-specific fecundity and secondary production}

At Stonehaven, the biomass of Pseudocalanus elongatus was generally higher than that of Oithona similis, except in September and November. The P. elongatus biomass had peaks in April and July to August, whereas the biomass of $O$. similis had peaks in April, but also in August to September (Figs. 7 \& 8). In the southern Kattegat, Pseudocalanus spp. biomass was greatest from April to June, while Oithona spp. biomass was greatest from late May through September (Kiørboe \& Nielsen 1994). Averaged across the whole year, mean copepodite ( $\mathrm{C} 1$ to adult) biomass was $0.5 \mathrm{mg} \mathrm{C} \mathrm{m}^{-3}$ (20.7 $\mathrm{mg} \mathrm{C} \mathrm{m}^{-2}$ when integrated over the water column) for $P$. elongatus, and $0.1 \mathrm{mg} \mathrm{C} \mathrm{m}^{-3}$ (integrated $=4.7 \mathrm{mg} \mathrm{C} \mathrm{m}^{-2}$ ) in $O$. simils in our study. Nielsen \& Sabatini (1996) found that Oithona spp. copepodite biomass in the North Sea varied from 0 to $\sim 200 \mathrm{mg} \mathrm{C}$ $\mathrm{m}^{-2}$ over the course of a $10 \mathrm{~d}$ spring cruise. Castellani et al.'s (2007) study on Oithona spp. in the North 
Atlantic gave a mean biomass (including nauplii) of $0.2 \mathrm{mg} \mathrm{C} \mathrm{m}^{-3}$ in the spring, and $1.1 \mathrm{mg} \mathrm{C} \mathrm{m}^{-3}$ in the summer. In $O$. similis, the highest seasonal mean in our study was in the summer, at $0.2 \mathrm{mg} \mathrm{C} \mathrm{m}{ }^{-3}$.

Weight-specific fecundity rates of both Pseudocalanus sp. and Oithona similis are compared across a range of locations in Table 4. In Pseudocalanus elongatus, the maximum weight-specific fecundity rate was observed in June, at $0.22 \mathrm{~d}^{-1}$, which is almost twice the maximum reported by Renz et al. (2008) of $0.13 \mathrm{~d}^{-1}$ in February in the southern North Sea. Kiørboe \& Johansen (1986) reported a weight-specific fecundity rate of $0.055 \mathrm{~d}^{-1}$ in September in the northern North Sea, stemming from a much lower egg production rate of just 2.0 eggs female ${ }^{-1} \mathrm{~d}^{-1}$.

Mean production rates for adult females over the year at Stonehaven were $8.9 \mathrm{\mu g} \mathrm{C} \mathrm{m}^{-3} \mathrm{~d}^{-1}$ in $P$. elongatus, and $1.9 \mu \mathrm{g} \mathrm{C} \mathrm{m}^{-3} \mathrm{~d}^{-1}$ in O. similis, the lower production rates of the latter reflecting the lower weightspecific fecundity and biomass of this species. Changes in population abundance and biomass between sampling dates for both species are not simply a consequence of mortality and growth rates of the populations. Biomass and weight-specific fecundity display strikingly different patterns over the course of the year and, as production is a composite of these 2 factors, this explains why production shows a different temporal pattern from weight-specific fecundity.

Acknowledgements. K.D. was supported by a Natural Environment Research Council studentship. We thank J. Fraser and J. Dunn of the Fishery Research Service (Marine Lab) in Aberdeen for help with taxonomy, field sampling, and use of facilities. T. FitzGeorge-Balfour kindly commented on an earlier draft of this work. We thank the anonymous reviewers for their helpful and constructive comments.

\section{LITERATURE CITED}

Atkinson D (1994) Temperature and organism size-a biological law for ectotherms? Adv Ecol Res 25:1-58

Ban SH, Lee HW, Shinada A, Toda T (2000) In situ egg production and hatching success of the marine copepod Pseudocalanus newmani in Funka Bay and adjacent waters off southwestern Hokkaido, Japan: associated to diatom bloom. J Plankton Res 22:907-922

Bonnet D, Harris RP, Yebra L, Guilhaumon F, Conway DVP, Hirst AG (2009) Temperature effects on Calanus helgolandicus (Copepoda: Calanoida) development time and egg production. J Plankton Res 31:31-44

Bunker AJ, Hirst AG (2004) Fecundity of marine planktonic copepods: global rates and patterns in relation to chlorophyll a, temperature and body weight. Mar Ecol Prog Ser 279:161-181

- Castellani C, Irigoien X, Harris RP, Holliday NP (2007) Regional and temporal variation of Oithona spp. biomass, stage structure and productivity in the Irminger Sea, North Atlantic. J Plankton Res 29:1051-1070

> Castellani C, Irigoien X, Mayor DJ, Harris RP, Wilson D (2008) Feeding of Calanus finmarchicus and Oithona similis on the microplankton assemblage in the Irminger Sea, North Atlantic. J Plankton Res 30:1095-1116

Checkley DMJ (1980) The egg production of a marine planktonic copepod in relation to its food supply: laboratory studies. Limnol Oceanogr 25:430-446

Chisholm LA, Roff JC (1990) Size-weight relationships and biomass of tropical neritic copepods off Kingston, Jamaica. Mar Biol 106:71-77

Corkett CJ, McLaren IA (1969) Egg production and oil storage by the copepod Pseudocalanus in the laboratory. J Exp Mar Biol Ecol 3:90-105

Corkett CJ, Zillioux EJ (1975) Studies on the effect of temperature on the egg laying of 3 species of calanoid copepods in the laboratory (Acartia tonsa, Temora longicornis and Pseudocalanus elongatus). Bull Plankton Soc Japan 21:77-86

Cushing DH (1975) Marine ecology and fisheries. Cambridge University Press, Cambridge

Dam HG, Peterson WT (1991) In situ feeding behaviour of the copepod Temora longicornis: effects of seasonal changes in chlorophyll size fractions and female size. Mar Ecol Prog Ser 71:113-123

> Dam HG, Miller CA, Jonasdottir SH (1993) The trophic role of mesozooplankton at $47^{\circ} \mathrm{N}, 20^{\circ} \mathrm{W}$ during the North Atlantic bloom experiment. Deep-Sea Res II 40:197-212

Devreker D, Souissi S, Winkler G, Forget-Leray J, Leboulenger $F$ (2009) Effects of salinity, temperature and individual variability on the reproduction of Eurytemora affinis (Copepoda; Calanoida) from the Seine estuary: a laboratory study. J Exp Mar Biol Ecol 368:113-123

> Dvoretsky VG, Dvoretsky AG (2009a) Spatial variations in reproductive characteristics of the small copepod Oithona similis in the Barents Sea. Mar Ecol Prog Ser 386:133-146

> Dvoretsky VG, Dvoretsky AG (2009b) Life cycle of Oithona similis (Copepoda: Cyclopoida) in Kola Bay (Barents Sea). Mar Biol 156:1433-1446

Eaton JM (1971) Studies on the feeding and reproductive biology of the marine cyclopoid copepod Oithona similis Claus. PhD thesis, Dalhousie University

Economou AN (1987) Ecology of survival in some gadoid larvae of the northern North Sea. Environ Biol Fishes 19: 241-260

> Edmondson WT, Comita GW, Anderson GC (1962) Reproductive rate of copepods in nature and its relation to phytoplankton population. Ecology 43:625-634

- Evjemo JO, Tokle N, Vadstein O, Olsen Y (2008) Effect of essential dietary fatty acids on egg production and hatching success of the marine copepod Temora longicornis. J Exp Mar Biol Ecol 365:31-37

Fransz HG, Mommaerts JP, Radach G (1991) Ecological modeling of the North Sea. Neth J Sea Res 28:67-140

$>$ Frost BW (1989) A taxonomy of the marine calanoid copepod genus Pseudocalanus. Can J Zool 67:525-551

Halsband C, Hirche HJ (2001) Reproductive cycles of dominant calanoid copepods in the North Sea. Mar Ecol Prog Ser 209:219-229

> Hay SJ, Evans GT, Gamble JC (1988) Birth, growth and death rates for enclosed populations of calanoid copepods. J Plankton Res 10:431-454

Heath MR (2007) The consumption of zooplankton by early life stages of fish in the North Sea. ICES J Mar Sci 64: 1650-1663

> Hirst AG, McKinnon AD (2001) Does egg production represent adult female copepod growth? A call to account for body weight changes. Mar Ecol Prog Ser 223:179-199

> Hirst AG, Peterson WT, Rothery P (2005) Errors in juvenile copepod growth rate estimates are widespread: problems 
with the Moult Rate method. Mar Ecol Prog Ser 296: 263-279

Hirst AG, Bonnet D, Harris RP (2007) Seasonal dynamics and mortality rates of Calanus helgolandicus over two years at a station in the English Channel. Mar Ecol Prog Ser 340: 189-205

> Hopcroft RR, Kosobokova KN (2010) Distribution and egg production of Pseudocalanus species in the Chukchi Sea. Deep-Sea Res II 57:49-56

Hopcroft RR, Roff JC (1996) Zooplankton growth rates: diel egg production in the copepods Oithona, Euterpina and Corycaeus from tropical waters. J Plankton Res 18: 789-803

> Huntley ME, Lopez MDG (1992) Temperature dependent production of marine copepods: a global synthesis. Am Nat 140:201-242

ICES (2005) The annual ICES ocean climate status summary 2004/2005. Cooperative Research Report No. 275, ICES, Copenhagen

Jónasdóttir SH, Visser AW, Jespersen C (2009) Assessing the role of food quality in the production and hatching of Temora longicornis eggs. Mar Ecol Prog Ser 382:139-150

Kauker F, von Storch H (2000) Statistics of "synoptic circulation weather" in the North Sea as derived from a multiannual OGCM simulation. J Phys Oceanogr 30:3039-3049

Kimmerer WJ, Hirst AG, Hopcroft RR, McKinnon AD (2007) Estimating juvenile copepod growth rates: corrections, inter-comparisons and recommendations. Mar Ecol Prog Ser 336:187-202

Kimoto K, Uye SI, Onbé T (1986) Egg production of a brackish-water calanoid copepod Sinocalanus tennellus in relation to food abundance and temperature. Bull Plankton Soc Japan 33:133-145

Kiørboe T, Johansen K (1986) Studies of a larval herring (Clupea harengus) patch in the Buchan area. IV. Zooplankton distribution and productivity in relation to hydrographic features. Dana 6:37-51

Kiørboe T, Nielsen TG (1994) Regulation of zooplankton biomass and production in a temperate, coastal ecosystem. 1. Copepods. Limnol Oceanogr 39:493-507

Kiørboe T, Mohlenberg F, Hamburger K (1985) Bioenergetics of the planktonic copepod Acartia tonsa: relation between feeding, egg production and respiration, and composition of specific dynamic action. Mar Ecol Prog Ser 26:85-97

Klein Breteler WCM, Fransz HG, Gonzalez SR (1982) Growth and development of four calanoid copepod species under experimental and natural conditions. Neth J Sea Res 16: 195-207

Koski M, Klein Breteler W, Schoft N (1998) Effect of food quality on rate of growth and development of the pelagic copepod Pseudocalanus elongatus (Copepoda, Calanoida). Mar Ecol Prog Ser 170:169-187

Koski M, Klein Breteler WK, Schogt N, Gonzalez S, Jakobsen $\mathrm{HH}$ (2006) Life-stage-specific differences in exploitation of food mixtures: diet mixing enhances copepod egg production but not juvenile development. J Plankton Res 28: 919-936

- Lampitt RS, Gamble JC (1982) Diet and respiration of the small planktonic marine copepod Oithona nana. Mar Biol 66:185-190

Legendre L, Rivkin RB (2002) Fluxes of carbon in the upper ocean: regulation by food-web control nodes. Mar Ecol Prog Ser 242:95-109

Liu H, Hopcroft RR (2008) Growth and development of Pseudocalanus spp. in the northern Gulf of Alaska. J Plankton Res 30:923-935

Mauchline J (1998) The biology of calanoid copepods. Adv
Mar Biol 33:253-256

McLaren IA (1963) Effects of temperature on growth of zooplankton, and the adaptive value of vertical migration. J Fish Res Board Can 20:685-727

McLaren IA, Avendaño P (1995) Prey field and diet of larval cod on Western Bank, Scotian shelf. Can J Fish Aquat Sci 52:448-463

Munk P (1997) Prey size spectra and prey availability of larval and small juvenile cod. J Fish Biol 51:340-351

Nakamura Y, Turner JT (1997) Predation and respiration by the small cyclopoid copepod Oithona similis: How important is feeding on ciliates and heterotrophic flagellates? J Plankton Res 19:1275-1288

Napp JM, Hopcroft RR, Baier CT, Clarke C (2005) Distribution and species-specific egg production of Pseudocalanus in the Gulf of Alaska. J Plankton Res 27:415-426

Nielsen TG, Sabatini M (1996) Role of cyclopoid copepods Oithona spp. in North Sea plankton communities. Mar Ecol Prog Ser 139:79-93

Nielsen TG, Møller EF, Satapoomin S, Ringuette M, Hopcroft RR (2002) Egg hatching rate of the cyclopoid copepod Oithona similis in Arctic and temperate waters. Mar Ecol Prog Ser 236:301-306

Ogilvie HS (1953) Zooplankton. Rapp P-V Reùn Cons Int Explor Mer 50:1-4

Otto L, Zimmerman JTF, Furnes GK, Mork M, Saetre R, Becker G (1990) Review of the physical oceanography of the North Sea. Neth J Sea Res 26:161-238

> Paffenhöfer GA (1993) On the ecology of marine cyclopoid copepods (Crustacea, Copepoda). J Plankton Res 15:37-55

Paffenhöfer GA, Harris RP (1976) Feeding, growth and reproduction of the marine planktonic copepod Pseudocalanus elongatus (Boeck). J Mar Biol Assoc UK 56:327-344

Peterson WT, Bellantoni DC (1987) Relationships between water-column stratification, phytoplankton cell size and copepod fecundity in Long Island Sound and off central Chile. S Afr J Mar Sci 5:411-421

Peterson WT, Kimmerer WJ (1994) Processes controlling recruitment of the marine calanoid copepod Temora longicornis in Long Island Sound: egg production, egg mortality, and cohort survival rate. Limnol Oceanogr 39:1594-1605

Plourde S, Runge JA (1993) Reproduction of the planktonic copepod Calanus finmarchicus in the lower St. Lawrence estuary: relation to the cycle of phytoplankton production and evidence for a Calanus pump. Mar Ecol Prog Ser 102:217-227

> Renz J, Peters J, Hirche HJ (2007) Life cycle of Pseudocalanus acuspes Giesbrecht (Copepoda, Calanoida) in the central Baltic Sea: II. Reproduction, growth and secondary production. Mar Biol 151:515-527

> Renz J, Mengedoht D, Hirche HJR (2008) Reproduction, growth and secondary production of Pseudocalanus elongatus Boeck (Copepoda, Calanoida) in the southern North Sea. J Plankton Res 30:511-528

> Runge JA (1985) Relationship of egg production of Calanus pacificus to seasonal changes in phytoplankton availability in Puget Sound, Washington. Limnol Oceanogr 30: 382-396

Runge JA, Roff JC (2000) The measurement of growth and reproductive rates. In: Harris RP, Wiebe P, Lenz J, Huntley M, Skojdal HR (eds) ICES zooplankton methodology manual. Academic Press, San Diego, CA, p 401-454

Sabatini M, Kiørboe T (1994) Egg production, growth and development of the cyclopoid copepod Oithona similis. J Plankton Res 16:1329-1351

Saiz E, Calbet A, Broglio E (2003) Effects of small-scale turbu- 
lence on copepods: the case of Oithona davisae. Limnol Oceanogr 48:1304-1311

Sazhina LI (1985) Nauplii of the major pelagic copepod species of the world's oceans. Naukova Dunka Press, Kiev (in Russian)

Schultz M, Kiørboe T (2009) Active prey selection in two pelagic copepods feeding on potentially toxic and nontoxic dinoflagellates. J Plankton Res 31:553-561

Svensen C, Kiørboe T (2000) Remote prey detection in Oithona similis: hydromechanical versus chemical cues. J Plankton Res 22:1155-1166

Uye SI (1982) Length-weight relationships of important zooplankton from the Inland Sea of Japan. J Oceanogr Soc Jpn 38:149-158

Uye S, Murase A (1997) Relationship of egg production rates of the planktonic copepod Calanus sinicus to phytoplank-

Editorial responsibility: William Peterson,

Newport, Oregon, USA ton availability in the Inland Sea of Japan. Plankton Biol Ecol 44:3-11

Uye S, Sano K (1995) Seasonal reproductive biology of the small cyclopoid copepod Oithona Davisae in a temperate eutrophic inlet. Mar Ecol Prog Ser 118:121-128

Vidal J (1980) Physioecology of zooplankton. 1. Effects of phytoplankton concentration, temperature, and body size on the growth rate of Calanus pacificus and Pseudocalanus sp. Mar Biol 56:134-146

Ward P, Hirst AG (2007) Oithona similis in a high latitude ecosystem: abundance, distribution and temperature limitation of fecundity rates in a sac spawning copepod. Mar Biol 151:1099-1110

- White JR, Roman MR (1992) Seasonal study of grazing by metazoan zooplankton in the mesohaline Chesapeake Bay. Mar Ecol Prog Ser 86:251-261

Submitted: March 15, 2010; Accepted: July 24, 2010

Proofs received from author(s): September 14, 2010 